TAO, Vol. 16, No. 2, 285-314, June 2005

\title{
REVIEW
}

\section{A Review on the Western North Pacific Monsoon: Synoptic-to-Interannual Variabilities}

\author{
$\operatorname{Tim} \mathrm{Li}^{1, *}$ and Bin Wang ${ }^{1}$ \\ (Manuscript received 14 October 2004, in final form 8 March 2005)
}

\begin{abstract}
In this paper we review the observed structure and evolution characteristics of the western North Pacific monsoon on various time scales, including its annual cycle, synoptic wave activity, intraseasonal oscillations, and interannual variabilities. On the synoptic (2-10-day) timescale, summertime synoptic waves and equatorial symmetric and anti-symmetric modes are often observed, and they may be responsible for triggering tropical cyclone genesis. On the intraseasonal scale, there are significant spectrum peaks at bi-weekly (10-20-day) and lower-frequency (20-70-day) bands. On the interannual time scale, the monsoon is greatly modulated by and possibly feeds back to the EI Niño-Southern Oscillation (ENSO). The paper reviews our current understanding of physical mechanisms that give rise to the synoptic-scale, intraseasonal and interannual variabilities, and multiscale interactions among these motions. The comparison between the Indian monsoon and the western North Pacific monsoons in terms of their differences in precipitation and circulation patterns, dominant time scales, and global teleconnection is also illustrated. Finally we discuss some remaining issues related to the western North Pacific monsoon variabilities.
\end{abstract}

(Key words: Monsoon-ocean interactions, Synoptic-scale wave trains and tropical cyclones, Bi-weekly and lower-frequency intraseasonal oscillations, Monsoon internnual variability, Teleconnection)

${ }^{1}$ Dept. of Meteorology and IPRC, Univ. of Hawaii, Honolulu, Hawaii, USA

* Corresponding author address: Prof. Tim Li, Dept. of Meteorology and IPRC, Univ. of Hawaii, Honolulu, Hawaii, USA; E-mail: timli@hawaii.edu 


\section{INTRODUCTION}

The Asian summer monsoon, the most energetic components of the earth's climate system, exhibits distinct regional characteristics. Differing from two continental monsoon components, the Indian summer monsoon (ISM) and the East Asian summer monsoon (EASM), the western North Pacific summer monsoon (WNPSM) is an oceanic monsoon driven primarily by meridional gradients of sea surface temperature (Tao and Chen 1987; Murakami and Matsumoto 1994). The WNPSM circulation is characterized by a northwest-southeast oriented monsoon trough with intense precipitation, low-level southwesterlies, and upper-tropospheric easterlies. The concept of the WNPSM was first introduced by Tao and Chen (1987). In analogy to a conceptual model of the Indian monsoon circulation that connects the Madacasca High to the India subcontinent (Krishnamurti 1976), Tao and Chen (1987) described the linkage of the WNPSM to the Australian High and cross-equatorial flows.

The core domain of the WNPSM was defined at $\left(110-160^{\circ} \mathrm{E}, 10-20^{\circ} \mathrm{N}\right)$ (Murakami and Matsumoto 1994). A boundary between the ISM and WNPSM appears to exist somewhere over South China Sea (SCS) where relative dry weather persists with a climatological OLR exceeding $230 \mathrm{~W} \mathrm{~m}^{-2}$, in contrast to a much smaller value of less than $190 \mathrm{~W} \mathrm{~m}^{-2}$ at updraft portions of the WNPSM and ISM. Wang and LinHo (2002) refined the definition of the WNPSM domain based on the onset, peak, and withdraw characters of climatological rainfall over the ISM, EASM and WNPSM regions (see Fig. 1). The EASM and WNPSM are separated by a remarkable discontinuity in the onset, peak, and withdrawal patterns along the southern flank of the western Pacific subtropical high (WPSH). The EASM advances progressively poleward from June to early September while the WNPSM withdraws equatorward after mid-September. The ISM and WNPSM, on the other hand, are separated by a broad transitional zone over Indochina in which a rainy season has double peaks occurring in September-October and May, a characteristic that differs substantially from rainy seasons over the ISM and WNPSM. Major differences between the ISM and WNPSM are as follows. The rainy season reaches its peak in June-July in the ISM region but in August-September in the WNPSM region. The onset of the ISM is characterized by a northward march of the rain belt over the Arabian Sea and a northwestward migration over the Bay of Bengal, both of which converge onto the Indian subcontinent. In contrast, the WNPSM consists of a three-phase development (see Fig. 1), which, to a large extent, is controlled by the climatological intraseasonal oscillation (ISO) (Wang and Xu 1997; LinHo and Wang 2002).

The WNPSM contains rich temporal spectrums, ranging from synoptic, intraseasonal, interannual, to interdecadal timescales. There also exist complex interactions among these timescales. For example, the WNPSM trough is a breeding ground for tropical cyclones (TCs), and its intraseasonal and interannual variations largely regulate the location of TC genesis. Pressure and wind anomalies over the WNP are crucial in linking the El Nino-Southern Oscillation (ENSO) to the East Asian climate (Wang et al. 1999; Chang et al. 2000a, b). Convective activities over the WNP exert considerable influence on the weather and climate in East Asia (Nitta 1987) and even in North America (Kawamura et al. 1996; Wang et al. 2001). Thus, understanding physical mechanisms behind motions at these scales and multi-scale interactions becomes critical for improving real-time weather and climate forecasts in the region. In 
Rainfall Peak (Julian) Pentad

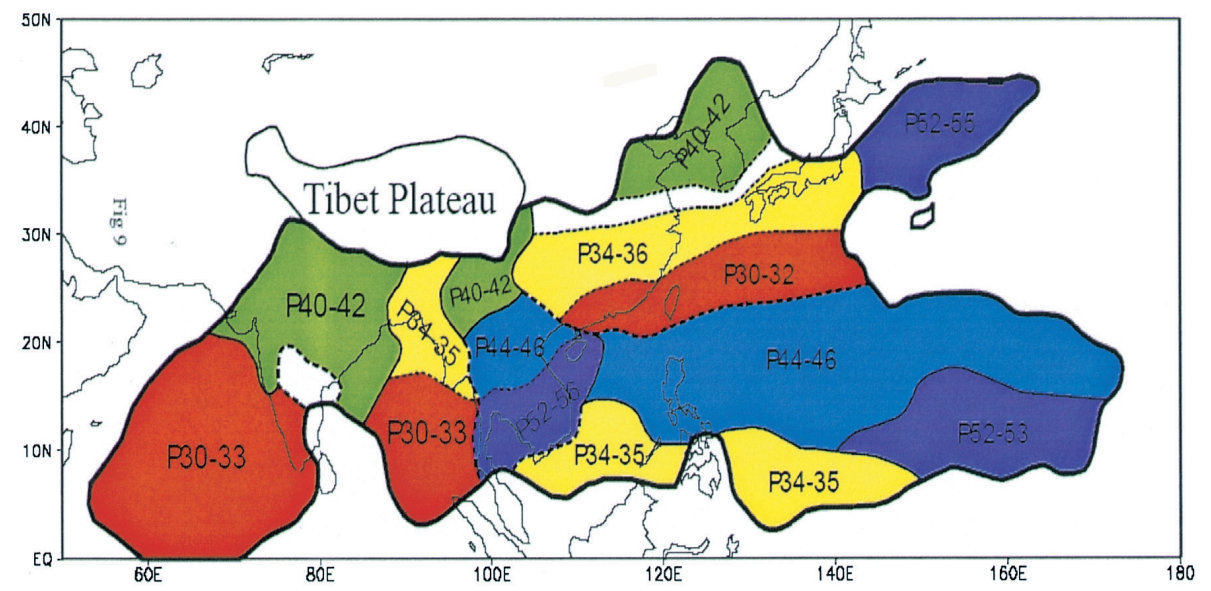

Division of Asia-Pacific Monsoon

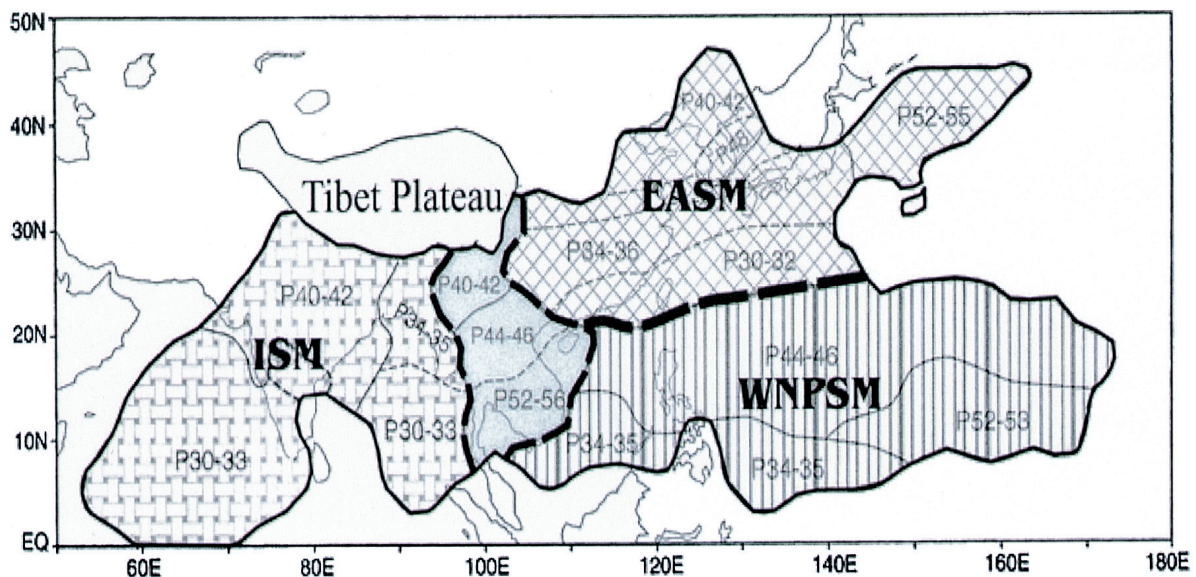

Fig. 1. Timing of monsoon rainfall peak (top panel): the Julian pentad during which the annual maximum rainfall occurs. The thick dotted lines indicate strong discontinuities. The rainfall peak pentads can be divided into four periods in the boreal summer, colored by light red (p30 - 33), yellow (p34 - 36), green (p40 - 42), blue (p44 - 46), and one period in boreal autumn, purple (p52 - 56). The lower panel divides the Asian-Pacific monsoon into three sub-regions. The ISM and WNPSM are tropical monsoon regions, and a broad corridor in the Indochina Peninsula separates them. The subtropical monsoon, EASM, shares a narrow borderline with the WNPSM. (adopted from Wang and Lin 2002) 
this paper we intend to review the current status of our understanding of the WNPSM on synoptic-to-interannual timescales.

\section{ONSET OF THE WNPSM AND CLIMATOLOGICAL ISO}

Climatologically, the summer monsoon displays a distinct step-wise northeastward advance in the SCS and the WNP (Wu and Wang 2000,2001). The monsoon rain commences first in the SCS in mid-May, extends into the southwestern Philippine Sea in mid-June, and jumps suddenly northeastward to around $20^{\circ} \mathrm{N}, 150^{\circ} \mathrm{E}$ in late-July. In association, the western North Pacific subtropical high displays a sudden eastward retreat or quick northward displacement, and the monsoon trough pushes abruptly eastward or northeastward at the onset stage (Wu and Wang 2001). The warmest SST tongue (over $29.5^{\circ} \mathrm{C}$ ) and high instability region feature a similar northeastward move in the SCS and WNP regions (Wu and Wang 2001; $\mathrm{Wu} 2002)$.

The exact cause of this northeastward movement of large-scale convection and SST fields is unclear. It was speculated that it might result from local air-sea interactions (Wu 2002). The monsoon-induced changes in cloudiness and surface winds produce contrasting changes in surface short wave radiation and latent heat flux between the convection and pre-convection regions (see the schematic diagram of Fig. 2). In the convection region, the increased cloudiness reduces the incoming short wave radiation, whereas the increased wind speed and the intrusion of monsoon disturbances enhance evaporation and oceanic mixing. Northeast of the convection region, the compensating downward motion in relation to the move of the subtropical high increases the incoming short wave radiation. Meanwhile, the decrease in wind speed and the suppression of high frequency disturbances in association with the move of the monsoon trough and the subtropical high reduce evaporation and oceanic mixing.

The contrasting change in surface heat fluxes induces a similar contrast for the change in SST tendency (Wu 2002). This leads to the reversal of the SST gradient east of the convection region in about one month, and induces the northeastward shift of the maximum SST center. Following the ocean surface warming in the pre-convection region, the convective instability and the low-level moisture convergence increase. East of the convection region, the reversal of the SST gradient tends to be associated with the transition of low-level winds from easterly to westerly. Thus, on one hand, the cloud-radiation and wind-evaporation feedback plays an important role for the seasonal change in SST, and on the other hand, the SST change induced by the monsoon onset facilitates the northeastward extension of convection. This suggests that the summer monsoon advance over the western North Pacific may result from air-sea interactions.

The onset of the summer monsoon over the WNP was found closely related to a climatological intraseasonal oscillation (CISO) in the region. The concept of CISO was introduced by Wang and Xu (1997), who noticed that ISOs with similar phases tend to occur around the same time each year. The CISO in the WNP has a dominant period of about 20 - 30 days, which may determine the time interval between the consecutive stages of the monsoon onset. Wang and $\mathrm{Xu}$ (1997) documented four CISO cycles in the monsoon domain. The wet phases 
of the first 3 CISO cycles occur, respectively, corresponding to the onset of the SCS monsoon, the onset of Meiyu/Baiu, and the peak of the WNPSM (also see Kang et al. 1999; Lin and Wang 2002). The stepwise onset has been speculated to result from the seasonal phase-locking of the ISO that interacts with the underlying ocean (Ueda et al. 1995; Wu and Wang 2000). Ueda et al. (1995) showed that the abrupt northward shift of convective anomalies over the western Pacific around $20^{\circ} \mathrm{N}, 150^{\circ} \mathrm{E}$ in late July is accompanied by a sudden appearance of large-scale cyclonic circulations and by changes in TC tracks.

\section{SYNOPTIC VARIABILITY}

\subsection{Synoptic-scale Wave Train}

The WNP is a favorable region for development of synoptic wave trains in boreal summer (e.g., Wallace and Chang 1969; Wallace 1971; Reed and Recker 1971; Lau and Lau 1990;

(a) Mid-May Change

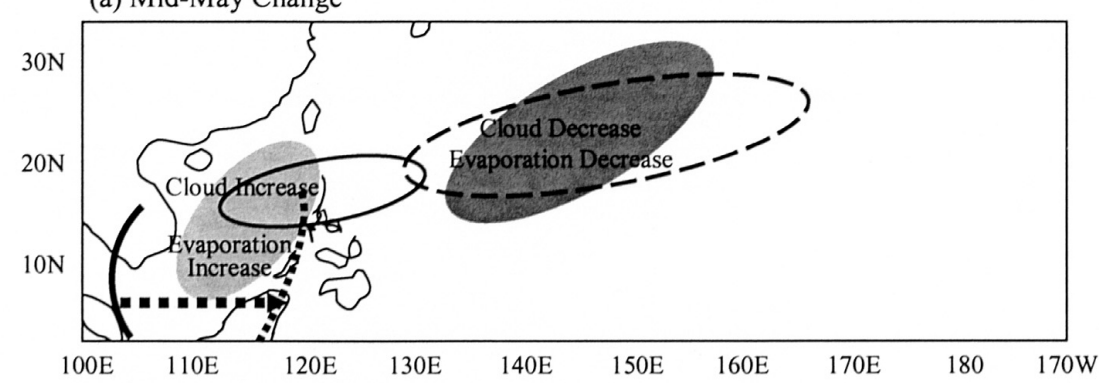

(b) Mid-June Change

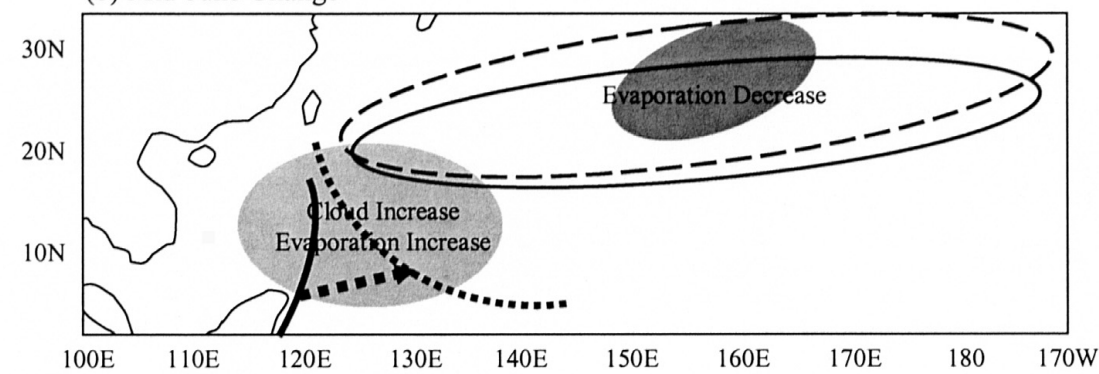

Fig. 2. Schematic diagrams for major changes at the mid-May (a) and mid-June (b) onset. The solid (dashed) lines denote the location of the monsoon trough before (after) the onset. The closed solid (dashed) curves indicate the subtropical high before (after) the onset. The light (heavy) shadings signify regions of increased (decrease) cloud and/or evaporation. The dashed arrows indicate the direction for the extension of low-level westerly winds. (from Wu 2002) 
Chang et al. 1996). Lau and Lau (1990) identified the northwest-southeast oriented synopticscale wave trains by analyzing the low-level vorticity and meridional wind fields. The wave train extends toward the southeast with a wave-like pattern that consists of alternating regions of cyclonic and anticyclonic circulations (Fig. 3), propagating northwestward along the confluence zone of the mean summer flow and extending from the equatorial western Pacific to Southeast Asia, with some exceptions reaching Indian subcontinent. The wave trains have a
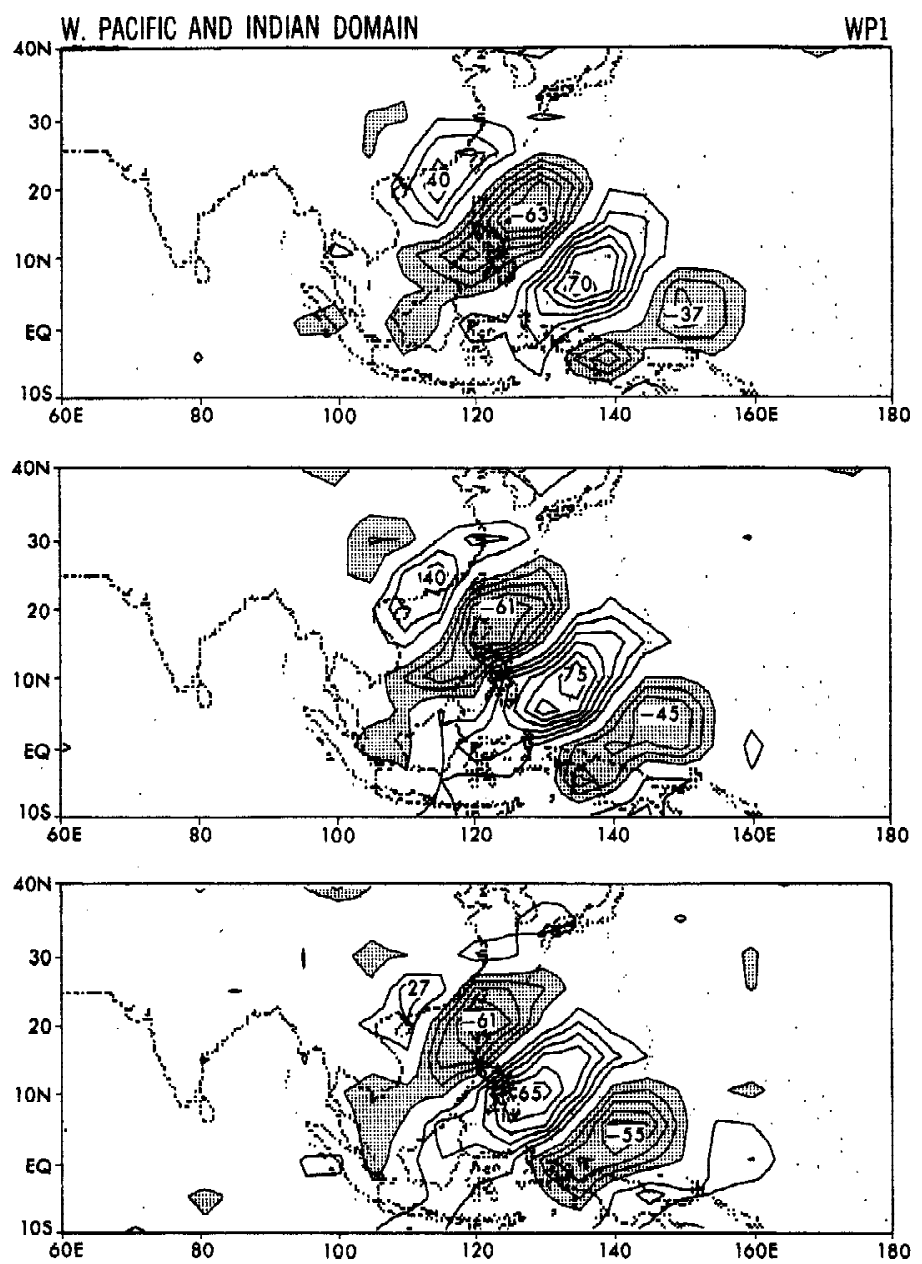

Fig. 3. Structures of the leading REEOF of band-pass-filtered vorticity fluctuations at $850 \mathrm{mb}$ in the western Pacific and Indian domain. The panels show time evolution in three consecutive days, with the upper panel leading the middle and lower panels by one and two days, respectively. Extrema are expressed in percent. Contour interval is $10 \%$. The zero contour has been omitted. (adapted from Lau and Lau 1990) 
typical wavelength of $2500-3000 \mathrm{~km}$ and a period of $6-10$ days. These tropical transients tend to propagate westward and/or northwestward over the WNP region, with an average phase propagation speed of about $5 \mathrm{~m} \mathrm{~s}^{-1}$.

The growth of the synoptic wave train appears in the large area over the western Pacific, which extends northwestward from around $0^{\circ} \mathrm{N}, 180^{\circ} \mathrm{E}$. These tropical disturbances cease to grow just off the coast of South China, and strong decay rates are discernible along the coast and farther inland.

The wave disturbances confine their maximum kinetic energy in the lower-troposphere, and are characterized by a westward tilt of vorticity anomalies with height in the vicinity of $135^{\circ} \mathrm{E}, 15^{\circ} \mathrm{N}$ (Lau and Lau 1990, Maloney and Esbensen 2003). A characteristic southwest to northeast oriented eddy structure is observed, indicating a barotropic conversion for energy source, in addition to latent heating in the middle troposphere (Lau and Lau 1992).

Various processes may cause the development of the synoptic-scale wave train. Among them are Rossby wave energy dispersion of a pre-existing mature TC (Holland 1995; Li et al. 2003) and a transition of equatorial mixed Rossby-gravity (MRG) waves (Liebmann and Hendon 1990; Takayabu and Nitta 1993; Dickinson and Molinari 2002). Using a linear shallow water model, Aiyyer and Molinari (2003) demonstrated that initial equatorial MRG waves in a background state similar to the convective phase of the Madden-Julian Oscillation (MJO) might evolve into off-equatorial tropical disturbances.

$\mathrm{Li}$ (2005) hypothesized that the origin of the synoptic wave train might result from the instability of the summer mean flow in the WNP in the presence of the convection-frictional convergence (CFC) feedback. This hypothesis was investigated with an anomaly atmospheric general circulation model (GCM) in which the observed 3D summer mean basic state is specified. The perturbation heating in the model is proportional to the divergence in the planetary boundary layer (PBL). Initially various types of perturbations were introduced. In the absence of the CFC feedback, the summer mean flow is not strong enough to excite instability to lead to the growth of perturbations. However, the mean flow determines the dynamic structure of the least damped mode, which has a northwest-southeast oriented wave train pattern and a typical wavelength of $2500 \mathrm{~km}$. In the presence of both the 3D mean flow and the CFC feedback, the model captures the most unstable mode in the WNP with a wave train structure and propagation speed similar to the observed.

The easterly waves are often observed off the equator in the WNP (e.g., Chang 1970; Fu 2003; Li et al. 2003). The propagation character and vertical structure of these waves may change systematically from the central to the western Pacific. Reed and Recker (1971) attributed this change to the longitudinal variation of the vertical shear in the ambient flow. Both the easterly waves and the wave train type disturbances are often related to TC genesis (Fu 2003). Ritchie and Holland (1999) suggested that roughly 50\% of western Pacific TCs form in association with these disturbances.

\subsection{Impact of the WNPSM on Tropical Cyclones}

When the axis of the WNP monsoon trough is in its normal orientation (NW-SE), TCs tend to move northwestward on tracks close to those expected from climatology (Lander 1996). 
As an episodic event, the axis of the monsoon trough extends farther north and east than normal and acquires a reverse (SW-NE) orientation. When the monsoon trough becomes reverse-oriented, TCs within it tend to exhibit north-oriented motion and other unusual motions such as eastward motion at low latitude and binary interactions with other TCs along the trough axis. Approximately $80 \%$ of the TCs that are associated with a reverse-oriented monsoon trough move on north-oriented tracks (Lander 1996). A TC track type, defined as the "S"-shaped track, is primarily associated with reverse orientation of the monsoon trough: 23 of 35 cases (66\%) of the "S" motion during the period 1978 - 94 occurred in association with a well-defined reverse-oriented monsoon trough.

The WNPSM exerts a great impact on tropical cyclogenesis. For instance, the confluence region between the monsoonal southwesterlies and the trade easterlies was identified as a frequent region of TC formation (Frank 1982; Briegel and Frank 1997). The dynamic interpretation is that this mean flow confluence tends to trap tropical waves in the mid- to lower troposphere through energy accumulation (Chang and Webster 1990; Holland 1995; Kuo et al. 2001). Ritchie and Holland (1999) summarized three large-scale flow patterns associated with cyclogenesis in the WNP: monsoon shear line, monsoon confluence, and monsoon gyre. Using the QuikSCAT surface wind and Tropical Rainfall Measurement Mission Microwave Image data, $\mathrm{Fu}$ (2003) documented various synoptic-triggering scenarios for the WNP cyclogenesis. Among them are Rossby wave energy dispersion from a pre-existing TC, easterly wave energy accumulation, and synoptic wave train activity. Using a 3D model, Li et al. (2003) demonstrated the importance of the monsoon mean flow in leading to cyclogenesis in the WNP.

Observational analysis reveals the vital impact of strong El Niño and La Niña events on TC genesis over the WNP (Wang and Chan 2002). Although the total number of TCs formed in the entire WNP region does not vary significantly from year to year, during the strong El Niño summer and fall, the frequency of TC formation increases remarkably in the southeast quadrant $\left(0-17^{\circ} \mathrm{N}, 140-180^{\circ} \mathrm{E}\right)$ and decreases in the northwest quadrant $\left(17-30^{\circ} \mathrm{N}, 120-\right.$ $140^{\circ} \mathrm{E}$ ). The enhanced TC formation in the SE quadrant might be attributed to the increase of low-level shear vorticity generated by El Niño-induced equatorial westerlies, while suppressed TC generation in the NW quadrant is possibly caused by a strengthening of the WNP subtropical high induced by El Niño forcing.

\section{INTRASEASONAL VARIABILITY}

The WNPSM is characterized by prominent active and break periods, which are closely associated with the ISO in the region (e.g., Murakami 1980; Lau and Chan 1986; Chen and Murakami 1988, Lau et al. 1988; Tanaka 1992; Ding 1992; Nakazawa 1992; Huang 1994; Wang and Xu 1997; Kang et al. 1999; Chen et al. 2000; Wu and Wang 2001). The active/break monsoons associated with the ISO are not only observed in the WNPSM, but also in the ISM (e.g., Yasunari 1979, 1980; Sikka and Gadgel 1980; Krishnamurti and Subrahmanyan 1982, and others) and the EASM regions (e.g., Lau and Chan 1986). The alternation between abrupt changes and steady evolution associated with the ISO is particularly evident in the EASM. 
The periodicity, amplitude, and propagation of the ISO exhibit strong geographical and seasonal dependence across the entire Asian monsoon region. It has been shown that there are two dominant periods over the WNP in boreal summer: a bi-weekly mode with a period of 10 - 20 days and a lower-frequency mode with a period of 20 - 70 days (Murakami 1980; Lau et al. 1988; Tanaka et al. 1992; Wang and Xu 1997; Fukutomi and Yasunari 1999; Kang et al. 1999, among others). The ISOs in the 10-20-day period (the bi-weekly mode) were previously noticed in the Indian monsoon region (e.g., Murakami 1976; Krishnamurti and Bhalme 1976; Yasunari 1979; Krishnamurti and Ardanuy 1980; Chen and Chen 1993; and others). High amplitude OLR fluctuations on the 10-25-day timescale were identified over the SCS by Fukutomi and Yasunari (1999), who noted that the OLR fluctuation on this timescale explains
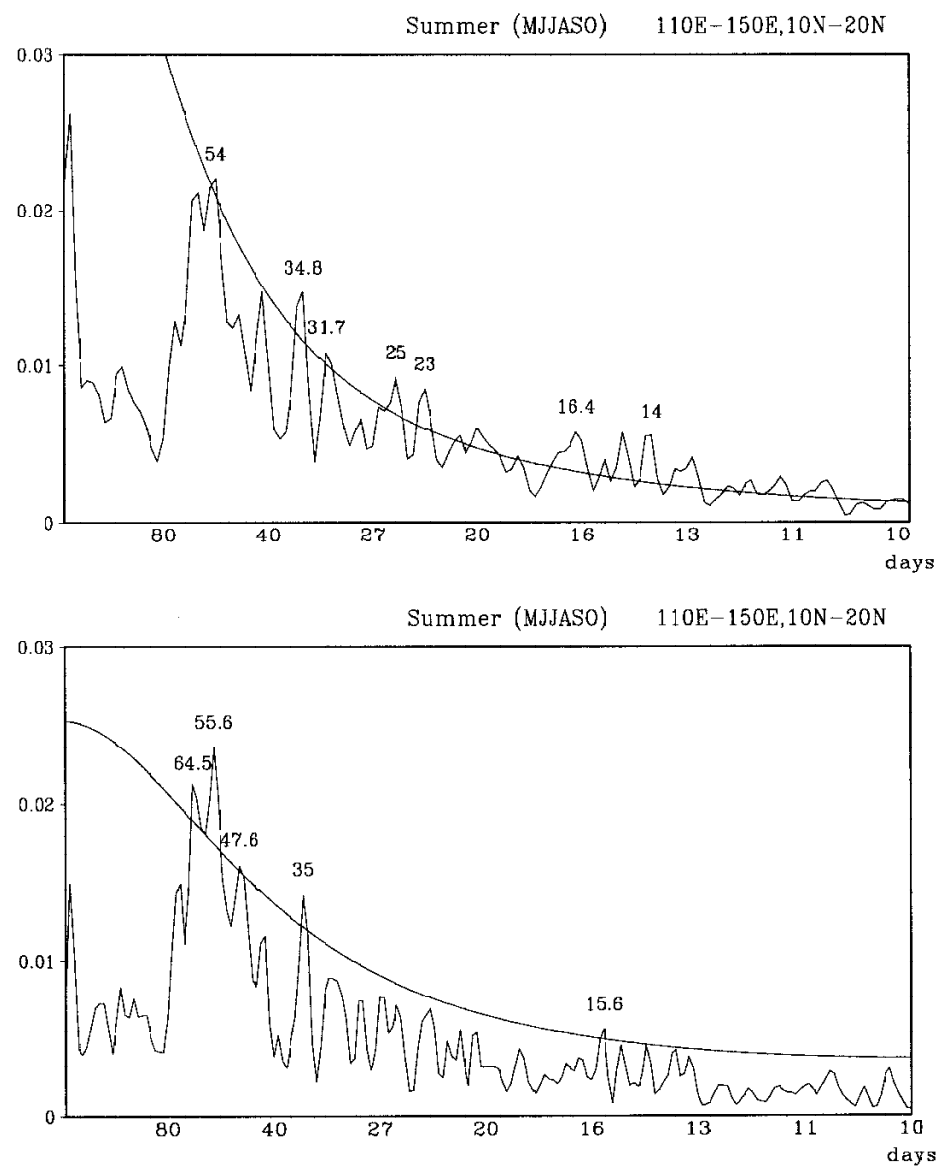

Fig. 4. Power spectra of observed daily OLR from NOAA satellites and pentad precipitation from the CMAP data, averaged over the WNPSM domain $\left(110-150^{\circ} \mathrm{E}, 10-20^{\circ} \mathrm{N}\right)$. The lines representing the $95 \%$ confidence level for the corresponding spectra are also plotted. 
more than $30 \%$ of total variance during the early summer (MJJ) season. Figure 4 illustrates the power spectra of observed daily OLR and 5-day mean CMAP precipitation fields over the summertime WNP. There are two well-separated groups of spectrum peaks around 20-70-day and 10-20-day periods. In contrast to boreal summer, a single frequency band with a period of 6 - 30 days dominates the winter ISO between $10^{\circ} \mathrm{N}$ and $30^{\circ} \mathrm{N}$ (e.g., Compo et al. 1999).

\subsection{ISO Subseasonal Variability}

The ISO life cycle was found to have significant differences between early and late summer (Kemball-Cook and Wang 2001). Kemball-Cook and Wang (2001) conducted a composite analysis of the life cycles of the ISO for the boreal summer periods of May-June (MJ) and August-October (AO) separately. Whereas the MJ composite shows strong eastward movement of convection along the equator in both the Indian Ocean and western Pacific, convection in the AO composite has a weak eastward-propagating signal along the equator and displays a discontinuous jump from the Indian Ocean to the western Pacific. In contrast to the MJ composite, the AO composite shows strong northwestward propagation of convection in the western Pacific. The change in the ISO life cycle from MJ to AO may be attributed to the seasonal shift in the distribution of basic-state vertical wind shear and low-level specific humidity fields.

The major OLR variance centers for the 20-70-day and 10-20-day bands during the early and late summer are illustrated in Fig. 5. The major 20-70-day variance in the early summer is located in the SCS. During this period, the 20-70-day variability in the WNP is weaker than the counterpart in the Arabian Sea and Bay of Bengal. In the late summer, the variability in the Arabian Sea, the Bay of Bengal, and the SCS weakens significantly, while the largest variability is observed in the Philippine Sea extending eastward to $170^{\circ} \mathrm{E}$. The major activity of the 20-70-day perturbations apparently shifts eastward from the Bay of Bengal and the SCS to the WNP during the seasonal march from early to late summer.

The 10-20-day ISO in general has a similar subseasonal variation except that the contrast in the Philippine Sea between the early and late summer is more prominent than that in the 20-70-day band. The amplitudes of the OLR variances in both ISO bands are similar.

\subsection{ISO Propagation and Structure}

Murakami (1980) first detected westward-propagating OLR signals over the WNP. Figure 5 shows propagation tendency vectors in the 20-70-day and 10-20-day OLR fields for the early and late summer. The propagation tendency vectors were calculated from the 5-day and 2-day lagged correlation maps for the 20-70-day and 10-20-day bands, respectively, following Lau and Chan (1986). The northwestward propagation tendency is clearly seen in both 20-70day and 10-20-day bands in the WNP.

Perhaps the most striking difference between the 10-20-day and 20-70-day variability lies in the propagation feature over the northern Indian Ocean. In the 20-70-day band, there is northeastward propagation tendency of convection from the Indian Ocean to SCS, which is 
propagation tendency and variance of bpf OLR
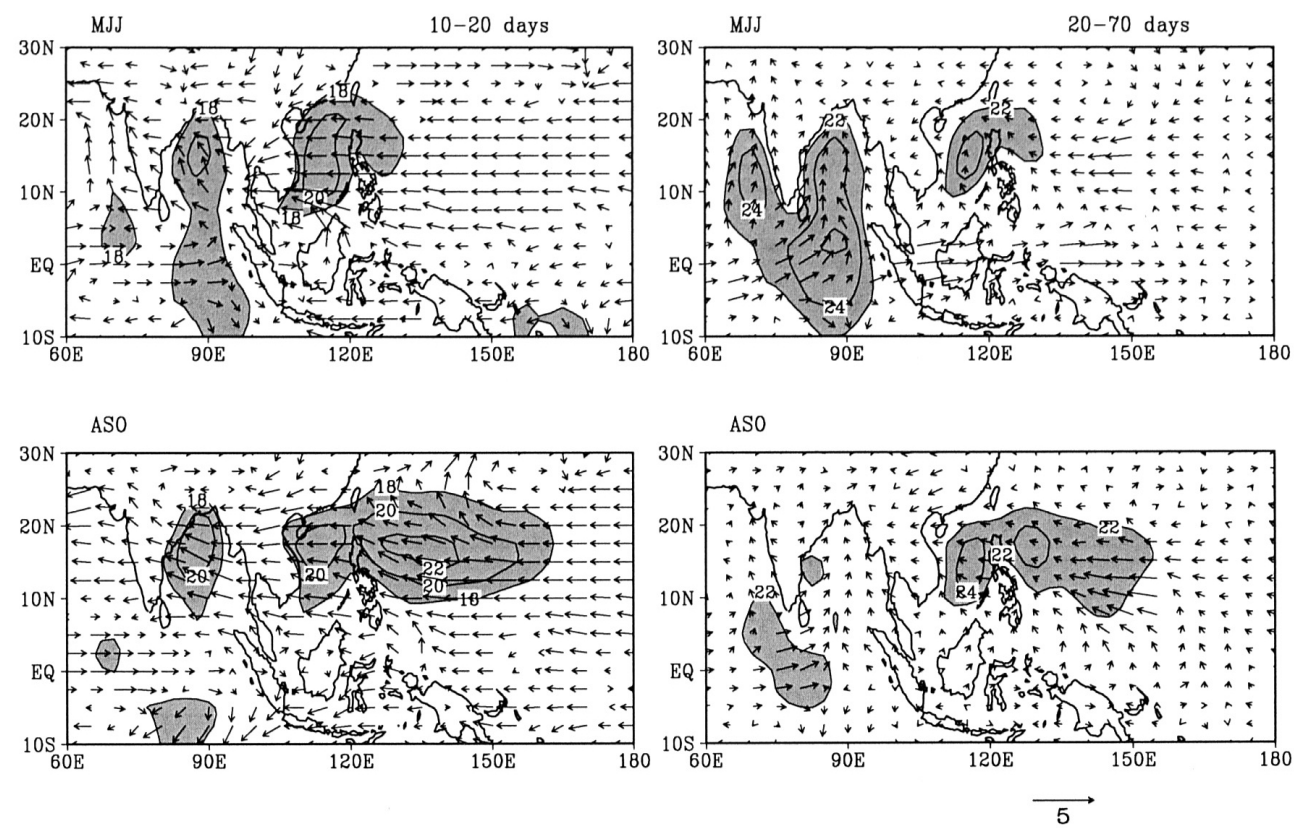

Fig. 5. OLR variance and propagation tendency vectors derived from the 5-day and 2-day lagged correlation maps for the 10-20-day (left) and 20-70day (right) bands for early (May-July) and late summer (August-October) respectively. The vector indicates the propagation direction and speed (unit: $\mathrm{m} \mathrm{s}^{-1}$ ), and areas with large variances of band-pass filtered OLR fields are shaded.

distinctive from the 10-20-day band in which there is westward and northwestward propagation tendency across the region from the early to late summer. The physical cause of such a distinctive propagation feature is unclear.

Kawamura et al. (1996) documented the circulation pattern associated with the northward propagation of 30-60-day ISO convection in the $110-160^{\circ} \mathrm{E}$ longitudinal band. A remarkable feature is the northward shift of the PBL convergence relevant to the convection center. Such a phase relationship was confirmed by Hsu and Weng (2001), who found that 850 -mb vorticity, while being in phase with the PBL convergence, leads to the convection (see Fig. 6). The northward shift of the vorticity may arise from the coupling of the baroclinic and barotropic modes in the presence of easterly shear of the mean flow (Jiang et al. 2004), and the combination of this effect with the beta effect may lead to the northwestward shift of the vorticity. The cyclonic vorticity at top of the PBL may further lead to frictional convergence and thus northwestward shift of convective heating. Hsu and Weng (2001) noticed that the surface latent 
heat flux does not significantly lead the ISO convection. This implies that the observed positive SST anomaly ahead of the convection may not actively contribute to the northwestward propagation; rather it is a passive response to atmospheric forcing due to reduced surface wind speed near the vorticity center.

Fukutomi and Yasunari (1999) noted that a downstream wave train extending from the SCS to North Pacific was built up in the lower troposphere associated with the 10-25-day
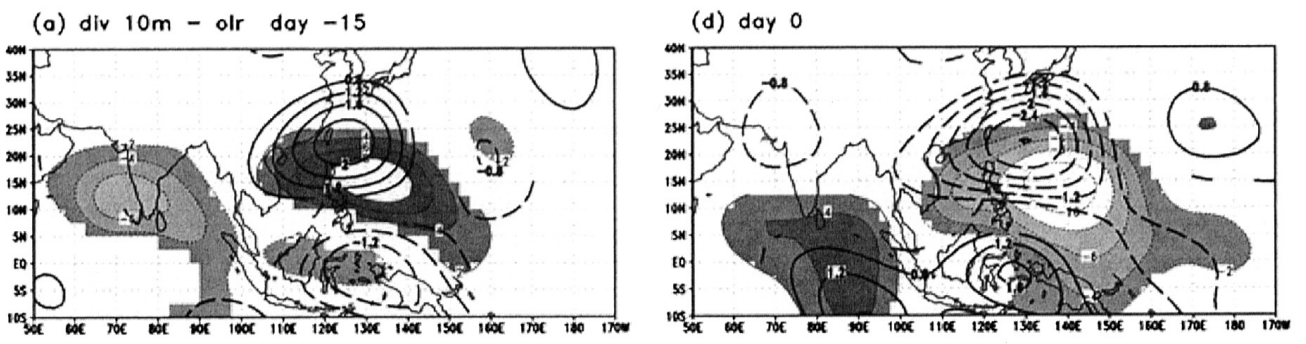

(b) day -10

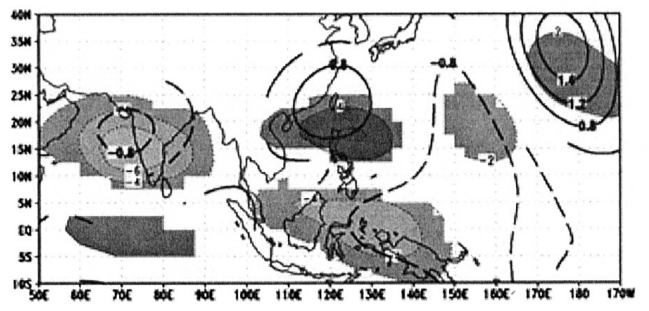

(e) day 5

(c) day -5
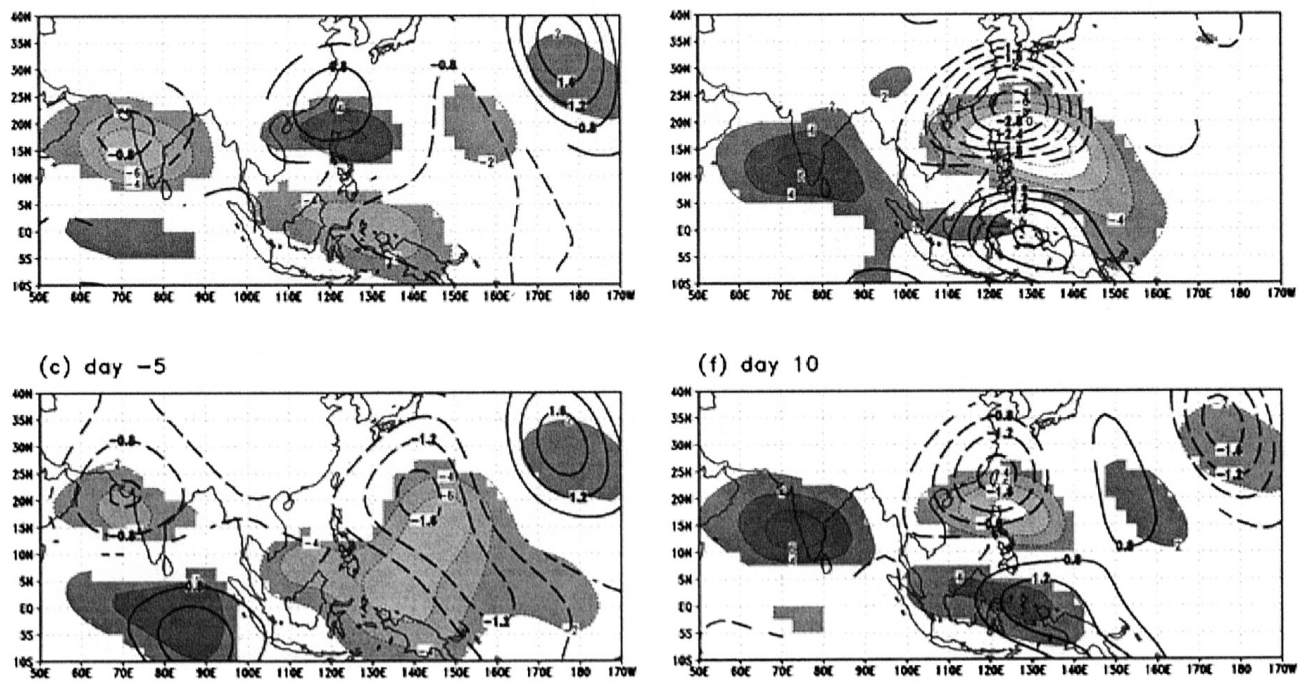

(f) day 10

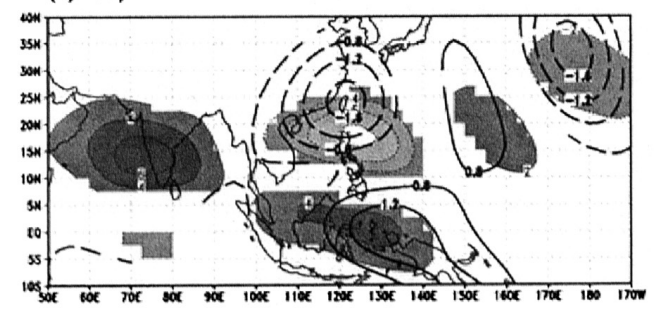

Fig. 6. Lagged regression coefficients between the convection index and the OLR (shaded) and 10-m divergence (contoured) at (a) day-15, (b) day10, (c) day-5, (d) day 0, (e) day 5, (f) day 10. Contour intervals are $2 \mathrm{Wm}^{-2}$ and $0.4 \times 10^{-6} \mathrm{~s}^{-1}$ for the OLR and $10-\mathrm{m}$ divergence, respectively. Dark shading and solid lines indicate positive values, while light shading and dashed (and dotted) lines indicate negative values. The regression coefficients have been multiplied by one standard deviation of the convection index and only those that are significant at the 0.05 level are plotted. (adapted from Hsu and Weng 2001) 
convective activity. This wave train was interpreted as a Rossby mode response to the anomalous ISO heating (cooling). Fukutomi and Yasunari (2002) further noted that circulation patterns associated with enhanced 10-25-day convection in June-July were significantly different from those in August. June-July composites show a significant Rossby wave train in both the lower and upper troposphere, extending from the convective region into the North Pacific along the mean westerly flow; in the lower troposphere, subtropical circulation anomalies as part of this wave train propagate southwestward along the subtropical duct. Tropical-extratropical linkage is less pronounced during August: Rossby waves do not emanate from the SCS and low-level subtropical circulation anomalies do not show southwestward phase propagation.

\subsection{Interannual Variability of the ISO}

The strength of ISO exhibits a year-to-year variability. A finite-domain wavenumberfrequency analysis was proposed to measure the interannual variability of the boreal summer ISO in the Asian-Pacific region (Teng and Wang 2003). The strongest interannual variations of the ISO are found in off-equatorial WNP. In summer when El Niño is developing, both westward and northwestward propagating waves are enhanced in July-October.

It is hypothesized that the ENSO affects the northwestward propagating ISO modes in the WNP through changing the mean circulation (Teng and Wang 2003). During July-October in the El Nino developing year, the easterly vertical shears over the tropical western Pacific are considerably increased, which in turn enhances Rossby wave development (Wang and Xie 1996) and thus reinforces ISO convective activities.

\subsection{ISO Control on TC Genesis}

Nakazawa (1986) found that TC formation tends to occur more frequently during the convectively active phase of the ISO at the 15-25-day and 30-60-day timescales in both Northern and Southern Hemisphere summers. This was confirmed by subsequent observational findings that the activity of 3-10 day tropical disturbances increases during the westerly phase of the MJO (Yamazaki ad Murakami 1989; Sui and Lau 1992; Maloney and Hartmann 2001; Straub and Kiladis 2003). Figure 7, adopted from Maloney and Dickinson (2003), presents the 2.5-12-day $850-\mathrm{hPa}$ vorticity variance during the entire June-August period, during the ISO westerly events, and during the ISO easterly events. The variance is largest in the ISO westerly phase and smallest in the ISO easterly phase, suggesting the large-scale ISO control of development of synoptic-scale disturbances and tropical cyclogenesis in the WNP.

\section{INTERANNUAL VARIABILITY}

\subsection{Leading Mode of the WNPSM Interannual Variability}

The WNPSM displays pronounced interannual variability (Tanaka 1997; Wang et al. 1999, 2001; Wu and Wang 2000; Chou et al. 2003). A dynamic WNP monsoon index (WNPMI) was defined by Wang and Fan (1999) to measure its interannual variability. The WNPMI is de- 

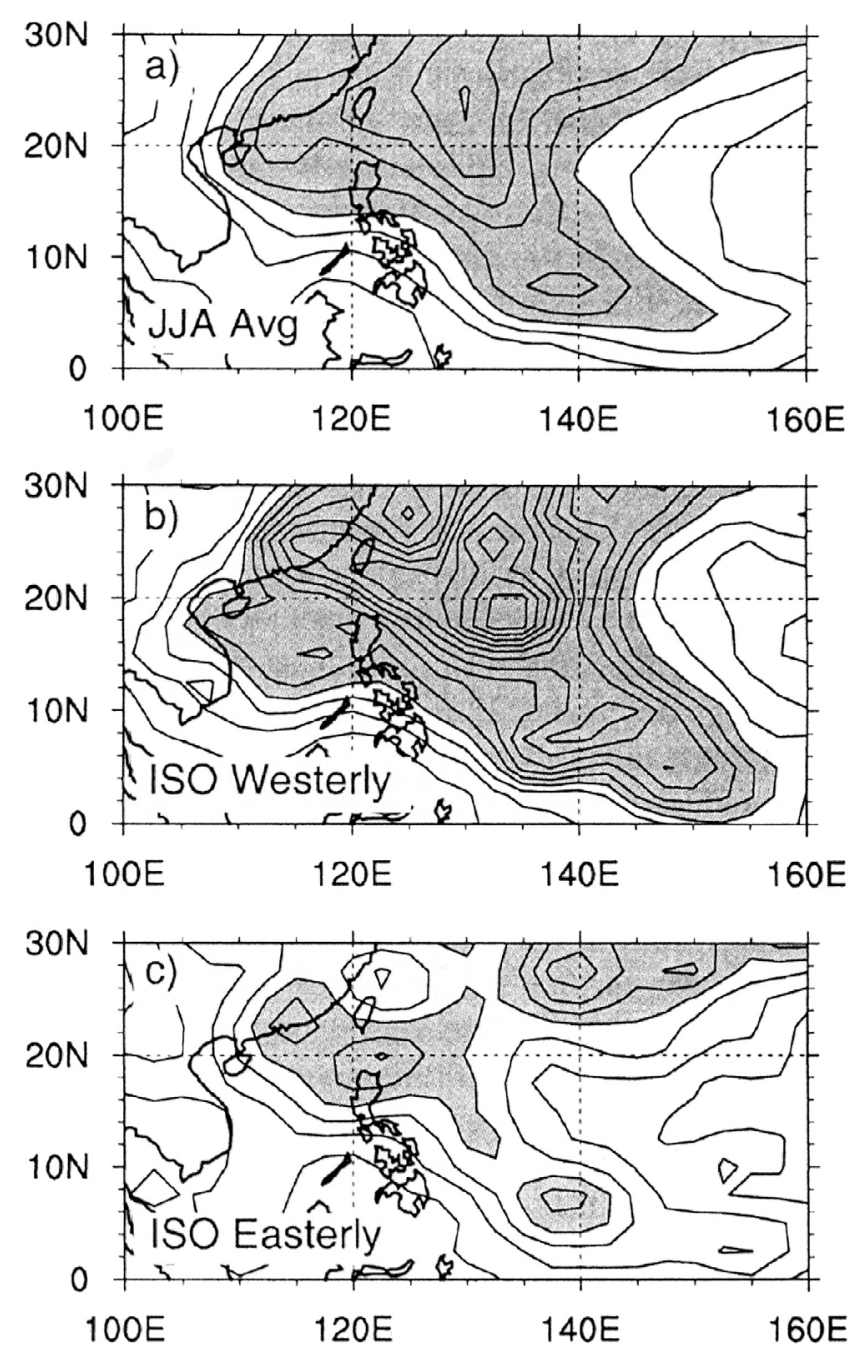

Fig. 7. The 850 -hPa perturbation vorticity variance in the 2.5-12-day band averaged during (a) June-August, (b) ISO westerly events, and (c) ISO easterly events. Contour interval is $2 \times 10^{-11} \mathrm{~s}^{-2}$. Values greater than $10 \times 10^{-11} \mathrm{~s}^{-2}$ are shaded. Adopted from Maloney and Dickinson (2003).

fined by the difference of $850 \mathrm{hPa}$ westerlies between the two regions $\left(5-15^{\circ} \mathrm{N}, 100-130^{\circ} \mathrm{E}\right)$ and $\left(20-30^{\circ} \mathrm{N}, 110-140^{\circ} \mathrm{E}\right)$. The leading EOF mode from the multivariate EOF analysis of $850 \mathrm{hPa}$ wind vectors enlightens about $22 \%$ of the total variance. The correlation coefficient between the corresponding time coefficient and the dynamic index is 0.88 for the 50 -yr period, which implies that the WNPMI indeed reflects the dominant mode. 
A strong WNPSM is characterized by increased rainfall over the SCS and WNP $\left(8^{\circ}-20^{\circ} \mathrm{N}\right.$, $110^{\circ}-180^{\circ} \mathrm{E}$ ) with a suppressed convective zone extending from Borneo to southern India (Fig. 8a), and a contrast of the SSTA between the SCS and central-eastern equatorial Pacific (Fig. 8b). The corresponding circulation anomalies are characterized by an anomalous cyclone (anticyclone) elongated along $20^{\circ} \mathrm{N}$ from 100 to $170^{\circ} \mathrm{E}$ and enhanced upper-level divergence over the Philippine Sea and associated easterlies and southward cross-equatorial flows over the Maritime Continent connected to an enhanced Australian high.

Compared to the ISM, the variations of the WNPSM display remarkable differences. The ISM has a dominant timescale of about 30 months, whereas the WNPSM shows two preferred timescales: one at the low-frequency ENSO timescale (about 50 months) (Wang et al. 2001),

(a) WNPMI strong minus weak year rainfall int: $1 \mathrm{~mm} /$ day shading: $95 \%$ sig.

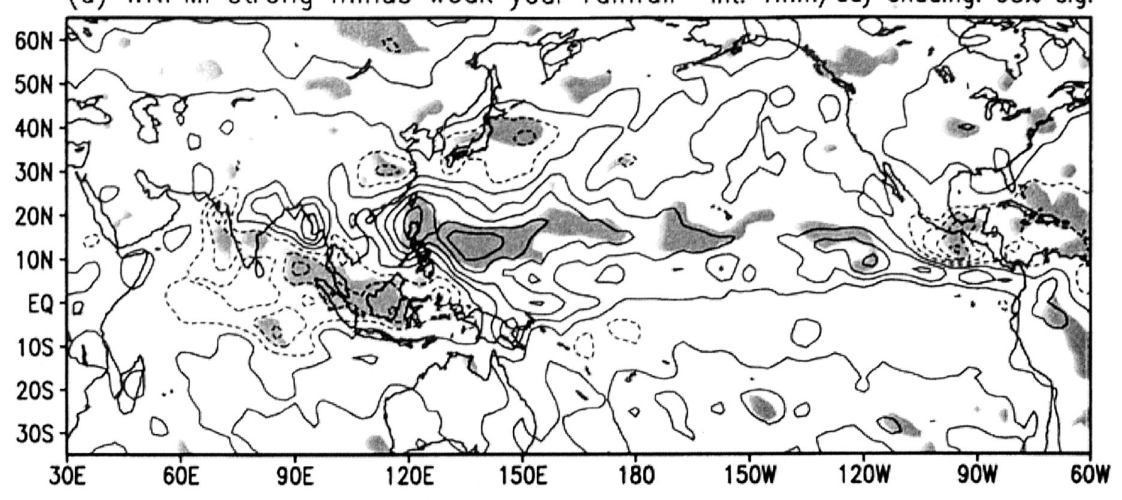

(b) WNPMI strong minus weak year JJA SST(Ts) int: $0.2 \mathrm{C}$ shoding: $95 \%$ sig.

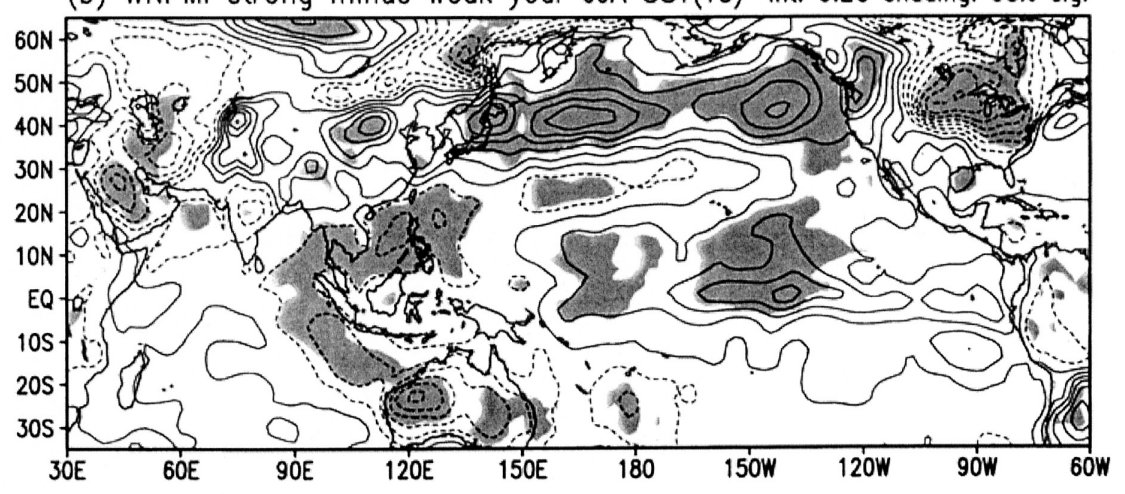

Fig. 8. Composite difference of (a) summer rainfall and (b) sea (land) surface temperature between the strong and weak monsoon years with respect to the WNPMI. The contour interval is $1 \mathrm{~mm} \mathrm{day}^{-1}$ for the rainfall and $0.2^{\circ} \mathrm{C}$ for SST. Shading denotes regions of difference at $95 \%$ confidence level. The rainfall data cover 1979 - 96 only. (From Wang et al. 2001) 
and the other at a quasi-biennial timescale (Meehl 1987; Rasmusson et al. 1990; Barnett 1991; Clarke et al. 1998). A strong ISM is characterized by 1) increased rainfall over India and the Bay of Bengal, 2) an enhanced low-level cross-equatorial gyre over the tropical Indian Ocean that connects with a deeper ISM trough to its north and a strengthened Mascarene high to its south, and 3) enhanced upper-level Tibetan Plateau and Mascarene highs and associated easterly anomalies over tropical Africa and the Indian Ocean. Strong (weak) ISM tends to occur in developing phases of ENSO cold (warm) episodes (e.g., Webster and Yang 1992; Ju and Slingo 1995). However, a strong (weak) WNPSM is often preceded by a mature phase of ENSO cold (warm) episode (Chang 2000a; Wang et al. 2000; Chou et al. 2003). The ISMENSO relation has remarkably weakened since the late 1970s concurrent with a decrease of the ISM variance (Kumar et al. 1999; Chang et al. 2001). The WNPSM-ENSO relationship, however, does not show significant interdecadal variations, even though the variance of the WNPSM has increased significantly since the late 1970s (Wang et al. 2001). In terms of the ENSO-monsoon relationship, the WNPSM appears to be more predictable than the ISM (Wang et al. 2001).

\subsection{Seasonal Evolution of Circulation Anomalies Associated with El Niño Turnabout}

Figure 9 displays the evolution of anomalous $850 \mathrm{hPa}$ winds and vertical p-velocity associated with ENSO turnabout revealed by the first extended singular vector decomposition (ESVD) mode (see Wang et al. 2003). This mode describes $91 \%$ of the total co-variance between the SST anomalies in the tropical Pacific and Indian Oceans $\left(40^{\circ} \mathrm{E}-90^{\circ} \mathrm{W}, 20^{\circ} \mathrm{S}-20^{\circ} \mathrm{N}\right)$ and five seasonal mean $850 \mathrm{hPa}$ wind anomalies.

During the summer when the El Niño develops, the low-level circulation anomalies are dominated by an elongated anticyclonic ridge extending from the maritime continent to the southern tip of India. Associated with this anticyclonic ridge is a tilted belt of pronounced anomalous westerlies extending from the Bay of Bengal to the WNP, suppressed convection over the maritime continent, and enhanced convection over the Philippine Sea (Fig. 9a). The enhanced WNP monsoon trough greatly increases the number of tropical storm formations in the southeast quadrant of the tropical WNP $\left(5^{\circ}-17^{\circ} \mathrm{N}, 140^{\circ}-170^{\circ} \mathrm{E}\right)(\mathrm{Chen}$ et al. 1998; Wang and Chan 2002). On the other hand, the weak anticyclonic anomalies over India imply a moderately deficient ISM.

During the fall of an El Niño developing year, the SIO anticyclone grows explosively, leading to a giant anticyclonic ridge dominating the Indian Ocean with the anticyclone center at $10^{\circ} \mathrm{S}, 90^{\circ} \mathrm{E}$; a titled ridge extending from western Australia all the way to the Arabian Sea (Fig. 9b). Note that a new anomalous low-level anticyclone starts to form in the vicinity of Philippines.

In the mature phase of El Niño, $\mathrm{D}(0) / \mathrm{JF}(1)$, the low-level circulation anomalies are dominated by two subtropical anticyclonic systems located in the SIO and the WNP, respectively (Fig. 9c). The former is a result of the weakening and eastward retreat of the SIO anticyclone from boreal fall, while the later results from the amplification and eastward migration of the Philippine anticyclone. The most suppressed convection centered east of the Philippines.

MAM(1) and JJA(1) have similar anomaly patterns, which are characterized by the pro- 
(a) $\mathrm{JJA}(0)$ wind $(850 \mathrm{hPa}) \&$ omego $(500 \mathrm{hPa})$

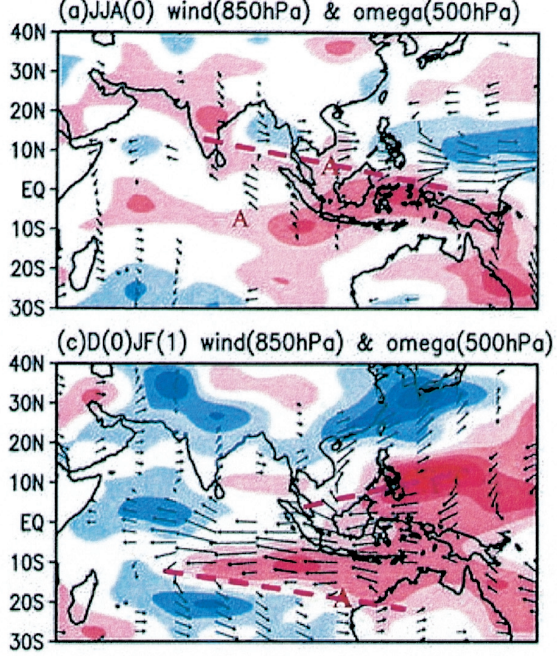

(e)JJA(1) wind $(850 \mathrm{hPa}) \&$ omega(500hPa)
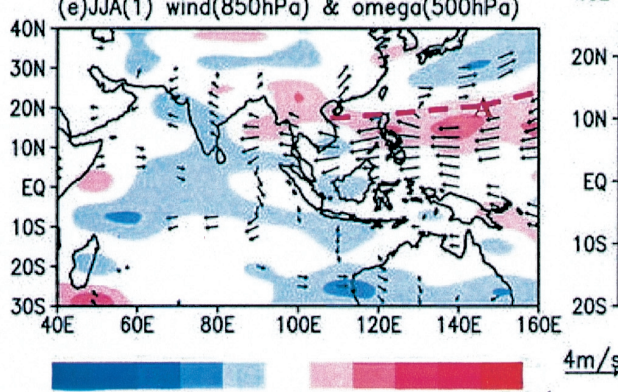

-3.6-2.8-2 -1.2-0.40.4 1.2 2 $2.8 \quad 3.6 \mathrm{~Pa} / \mathrm{s}$

(g)temporal amplitude

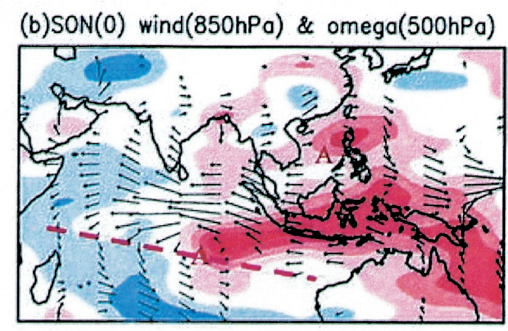

(d) MAM(1) wind $(850 \mathrm{hPa})$ \& omega $(500 \mathrm{hPa})$

$\mathrm{m} / \mathrm{s}$

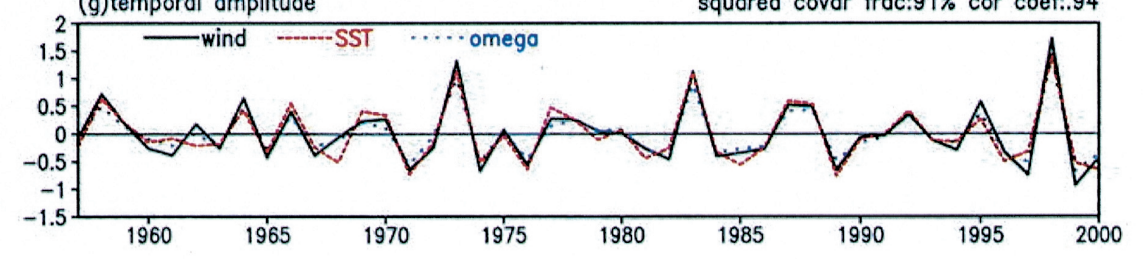

Fig. 9. The spatial patterns of the dominant ESVD mode (a-f) and the corresponding time coefficients $(\mathrm{g})$ of the wind and SST anomalies. (a)-(e) show the seasonal mean $850 \mathrm{hPa}$ winds (vectors) and $500 \mathrm{hPa}$ vertical pvelocity (color shading) from JJA(0) to JJA(1), where year 0 and year 1 denote the year during which an El Niño develops and the following year, respectively. Only wind anomalies significant at the $95 \%$ confidence level are shown. (f) shows seasonal mean SST anomalies in $\mathrm{D}(0) / \mathrm{JF}(1)$. The numbers on the top-right of $(\mathrm{g})$ are the squared covariance fraction between wind and SST anomalies (0.91) and the correlation coefficient between the two time series (0.94). 
nounced WNP anomalous anticyclone (Figs. 9d, e). The intensity of the WNP anticyclone however, decreases toward JJA(1). By summer JJA(1), subsidence controls the Philippine Sea and Southeast Asia, signifying weakening of the summer monsoon over the WNP and south Asia. The anomaly pattern exhibits nearly opposing polarities with that in the summer of the previous year, indicating a biennial tendency associated with the El Niño turnabout.

The most interesting feature of the WNPSM is its weakening during the El Niño decaying phase and strengthening during the El Niño developing phase. This raises important questions as to how El Niño exerts simultaneous and delayed impacts on the WNP anomalous circulation.

\subsection{Causes of the Interannual Variability}

The interannual variability of the WNPSM is closely related to ENSO (e.g., Zhang et al. 1996; Chang et al. 2000a, b; Wang et al. 2000; Zhang and Sumi 2002; Chou et al. 2003). Table 1 lists the strong and weak monsoon years via three categories of the ENSO developing year, ENSO decaying year and non-ENSO year by Chou et al. (2003). A strong (weak) WNP summer monsoon tends to occur in the El Niño (La Niña) developing year and the La Niña (El Niño) decaying year. Without the ENSO influence, the interannual variability of the WNP summer monsoon does not link to the tropical eastern Pacific SST

The anomalous WNPSM may result from different processes in the non-ENSO, ENSO developing, and ENSO decaying years (Chou et al. 2003). In the non-ENSO years, the variation of the meridional upper-tropospheric temperature gradient may contribute to the anomalous monsoon. In the ENSO developing years, it may be related to remote forcing from the eastern Pacific SST anomalies. In the ENSO decaying year, the western Pacific SST anomalies may be a dominant factor.

The process through which the ENSO has a delayed impact on the WNPSM was illustrated by Wang et al. (2000) (see a schematic diagram in Fig. 10) and further explored by Wang and Zhang (2002). In their proposed mechanism, the development of the anomalous Philippine Sea anticyclone (PSAC) plays an essential role. The PSAC persists from the mature El Niño to the ensuing summer, which strengthens the western Pacific subtropical ridge in the early summer after the peak ENSO warm events. The persistence of the PSAC is proposed to be resulted from the positive thermodynamic feedback between atmospheric descending Rossby waves and the underlying cold SST anomaly to the east of the PSAC center. This positive feedback operates in the presence of background northeasterly monsoon or trade winds. To the east of the anomalous PSAC, the increased total wind speed cools the ocean surface where it induces excessive evaporation and entrainment. The cooling, in turn, suppresses convection and reduces latent heating in the atmosphere, which excites descending atmospheric Rossby waves that reinforce the PSAC in their decaying journey to the west.

In contrast to its weakening in the El Nino decaying summer, the WNPSM tends to strengthen in the El Niño developing summer (see Fig. 9a). Two possible processes may contribute to this strengthening. The first is through the direct response to central Pacific heating anomalies. Compared to its mature phase, maximum SST anomalies in the El Niño developing summer are located more toward the west near the central equatorial Pacific where the mean SST is higher. This leads to a greater impact to the western Pacific in summer than in winter 
Table 1. Classification of the interannual variability by using Wang and Fan (1999)'s definition via three categories of ENSO developing year, ENSO decaying year and non-ENSO year. The * denotes either a year with both ENSO developing and decaying phases in the same calendar year or a year with ENSO persisting from the previous year to the following year. (from Chou et al. 2003)

\begin{tabular}{|c|c|c|c|}
\hline Years & & ENSO (DJF) & WNP summer monsoon \\
\hline 1951 & & Non-ENSO & Strong \\
\hline 1952 & & Non-ENSO & Strong \\
\hline 1953 & & Non-ENSO & Strong \\
\hline 1954 & & La Niña developing & Weak \\
\hline 1955 & * & La Niña persisting & Weak \\
\hline 1956 & & La Niña decaying & Weak \\
\hline 1957 & & El Niño developing & Weak \\
\hline 1958 & & El Niño decaying & Weak \\
\hline 1959 & & Non-ENSO & Weak \\
\hline 1960 & & Non-ENSO & Strong \\
\hline 1961 & & Non-ENSO & Strong \\
\hline 1962 & & Non-ENSO & Strong \\
\hline 1963 & & Non-ENSO & Strong \\
\hline 1964 & & Non-ENSO & Weak \\
\hline 1965 & & El Niño developing & Strong \\
\hline 1966 & & El Niño decaying & Weak \\
\hline 1967 & & Non-ENSO & Strong \\
\hline 1968 & & El Niño developing & Weak \\
\hline 1969 & & El Niño decaying & Weak \\
\hline 1970 & & La Niña developing & Weak \\
\hline 1971 & & La Niña decaying & Weak \\
\hline 1972 & & El Niño developing & Strong \\
\hline 1973 & $*$ & El Niño decaying and La Niña developing & Weak \\
\hline 1974 & & La Niña decaying & Strong \\
\hline 1975 & & La Niña developing & Weak \\
\hline 1976 & & La Niña decaying & Strong \\
\hline 1977 & & Non-ENSO & Weak \\
\hline 1978 & & Non-ENSO & Strong \\
\hline 1979 & & Non-ENSO & Strong \\
\hline 1980 & & Nôn-ENSO & Weak \\
\hline 1981 & & Non-ENSO & Strong \\
\hline 1982 & & El Niño developing & Strong \\
\hline 1983 & & El Niño decaying & Weak \\
\hline 1984 & & La Nina developing & Strong \\
\hline 1985 & & La Niña decaying & Strong \\
\hline 1986 & & El Niño developing & Strong \\
\hline 1987 & & El Niño decaying & Weak \\
\hline 1988 & & La Niña developing & Weak \\
\hline 1989 & & La Niña decaying & Strong \\
\hline 1990 & & Non-ENSO & Strong \\
\hline 1991 & & El Niño developing & Strong \\
\hline 1992 & & El Niño decaying & Strong \\
\hline 1993 & & Non-ENSO & Weak \\
\hline 1994 & & El Niño developing & Strong \\
\hline 1995 & & El Niño decaying & Weak \\
\hline 1996 & & Non-ENSO & Weak \\
\hline 1997 & & El Niño developing & Strong \\
\hline 1998 & $*$ & El Niño decaying and La Niña developing & Weak \\
\hline 1999 & $*$ & La Niña persisting & Strong \\
\hline 2000 & & La Niña decaying & Strong \\
\hline
\end{tabular}


even though the SSTA amplitude is greater in DJF. In response to this greater heat source in the central Pacific, low-level cyclonic flows are established, enhancing the convective activity in the WNP in summer. Secondly, the suppressed convection over the maritime continent (in response to enhanced convection in the central Pacific) leads to an equatorial-asymmetric Rossby wave response due to the mean flow asymmetry (Wang et al. 2003). This leads to a strong anticyclonic cell to the north of the equator, with an anomalous ridge tilted northwestward toward the Indian subcontinent. As a result, monsoon rainfall over India is suppressed. Meanwhile, the anomalous anticyclonic flow enhances low-level westerlies and thus convective activities over the WNP. This explains why the rainfall anomalies over India and WNP often have an opposite sign in the El Niño developing summer.

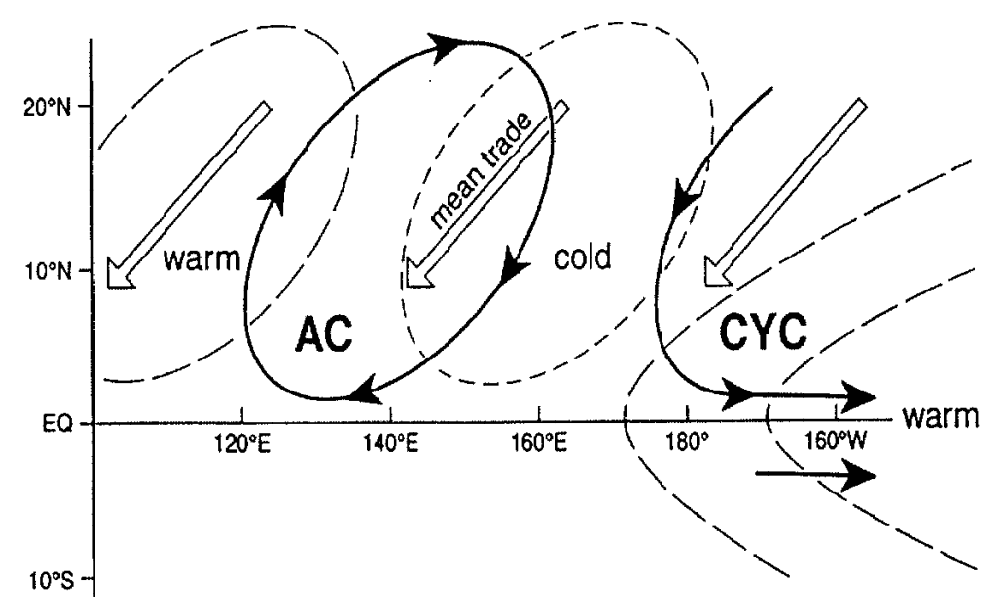

Fig. 10. Schematic diagram showing the air-sea interaction in the western North Pacific that maintains the Philippine Sea anticyclonic anomalies and associated negative SST anomalies in the western North Pacific. The double arrows denote the mean trade winds. The heavy lines with black arrows represent the anomalous winds. The long (short) dashed lines indicate contours of positive (negative) SST anomalies. (from Wang et al. 2000)

\section{GLOBAL TELECONNECTION}

\subsection{Japan-Pacific Pattern}

The WNPSM has profound impacts on the EASM. Nitta (1987) and Huang and Wu (1989) found that rainfall anomalies associated with the Meiyu/Baiu front are correlated with variations of the convective activity over the Philippine Sea. It was suggested that the atmospheric Rossby wave caused by the anomalous convective activities over the tropical NWP can propagate from the tropics to the extratropics and leads to the interannual variability of the EASM (Nitta 1987; Huang and Sun 1992; Wang et al. 2001). Therefore, corresponding to a strong 
WNPSM, deficient rainfall occurs in the East Asian subtropical monsoon front extending from the lower reach of the Yangtze River valley to Japan. This teleconnection pattern is named as the Japan-Pacific (JP) pattern.

During summer, the location and strength of the WNP subtropical high (WNPSH) has a direct influence on the East Asian summer (Ninomiya and Kobayashi 1998, 1999; Chang et al. 2000ab; Lu 2001; Zhang et al. 2004). A strong WNPSH may result from positive feedback that involves the anomalous Hadley and Walker circulations (Wang 1995; Li 1997; Zhang and Jiang 2000), an atmospheric Rossby wave response to the western Pacific cooling (Wang et al. 2000), anomalous heating over Tibetan Plateau (Wu et al. 2002), and/or intensification of atmospheric convection over the warm pool (Lu and Dong 2001). The maintenance of a strong WNPSH may modulate the strength and duration of the subtropical Meiyu front (Chang et al. 2000a, b). The WNPSH blocks the Meiyu front, thereby increasing the duration of the stationary rainfall. It also enhances the pressure gradient to its northwest, resulting in a more intense front. As a result, heavy rainfall occurs near the northwestern boundary of the WNPSH.

\subsection{WNP-North America Teleconnection}

The teleconnection associated with anomalous WNPSM has a profound impact on North America in both intraseasonal and interannual timescales (Kawamura 1996; Lau and Weng 2000, 2002; Wang et al. 2001; Lau et al. 2004). Wang et al. (2001) showed that during a strong WNPSM, a pronounced wave train pattern, seen in the lower, mid-, and upper troposphere, emanates from the WNP, crosses the North Pacific and extends to North America (Figs. 11, $12 b)$. The wave train consists of five major cells. They are, respectively, an east-west elongated cyclone along $20^{\circ} \mathrm{N}$ in the subtropical WNP off the coast of East Asia, an elongated anticyclone along $35^{\circ} \mathrm{N}$ extending from the Yellow Sea to the date line, an elongated cyclone extending from the Okhotsk Sea to the Bering Sea, an anticyclone over the Gulf of Alaska and northwestern Canada, and a cyclone over the Great Lakes of North America. The wave train exhibits a dominant barotropic structure north of $30^{\circ} \mathrm{N}$ while in the Tropics between $10^{\circ}$ and $30^{\circ} \mathrm{N}$ the circulation exhibits a baroclinic structure (Fig. 11).

The summer wave train depicted in Figs. 11 and 12 suggests a linkage between the climate anomalies over North America and the WNP. A weak WNPSM (suppressed convection in the WNP) implies an anomalous cyclone located in the Gulf of Alaska and northwest Canada (centered at $55^{\circ} \mathrm{N}, 130^{\circ} \mathrm{W}$ ) and an anomalous anticyclone over the Great Lakes $\left(50^{\circ} \mathrm{N}, 90^{\circ} \mathrm{W}\right)$. Using the 50-yr (1948 - 97) data, Wang et al. (2001) obtained a significant correlation coefficient $(0.42)$ between the WNPMI and the U.S. Great Plains precipitation. Two possible mechanisms through which the WNP heat source may affect the North American climate have been speculated by Wang et al. (2001). One is through the heating-induced meridional circulation that perturbs the midlatitude jet stream, which in turn excites optimum downstream circulation anomaly mode. Another possible mechanism may be at work when the anomalous WNP heat source is centered north of $20^{\circ} \mathrm{N}$ so that the midlatitude westerlies allow the generation of the Rossby wave train to North America. Lau et al. (2004) suggests that local air-sea interactions over the North Pacific may enhance signals generated by convection over the western Pacific.

The teleconnection patterns associated with the ISM and WNPSM are remarkably different. 


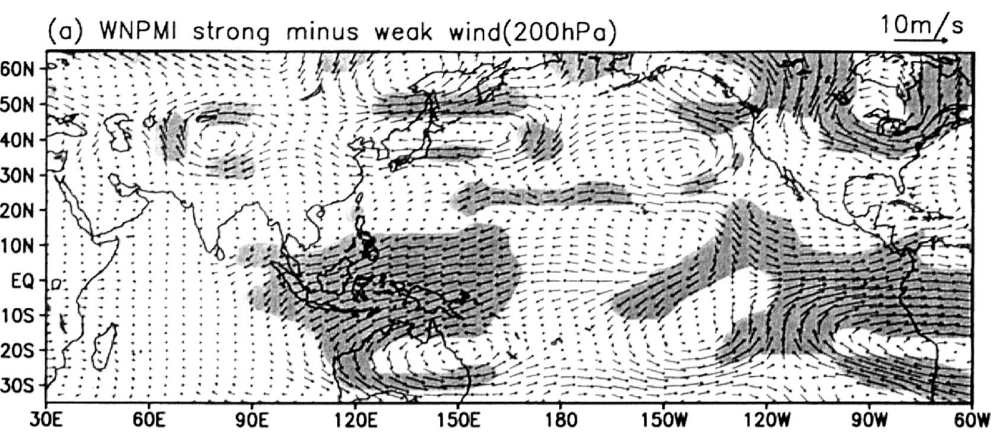

(b) WNPMI strong minus weak height $(500 \mathrm{hPa})$

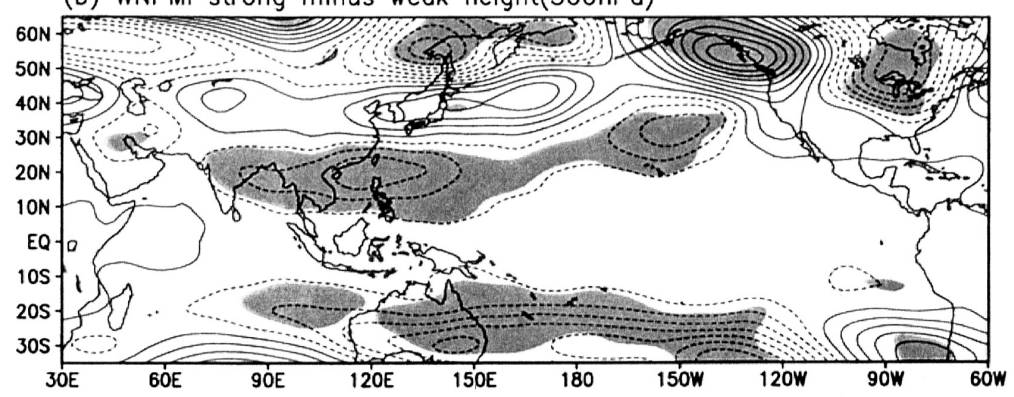

(c) WNPMI strong minus weak wind $(850 \mathrm{hPa})$

$5 \mathrm{~m} / \mathrm{s}$

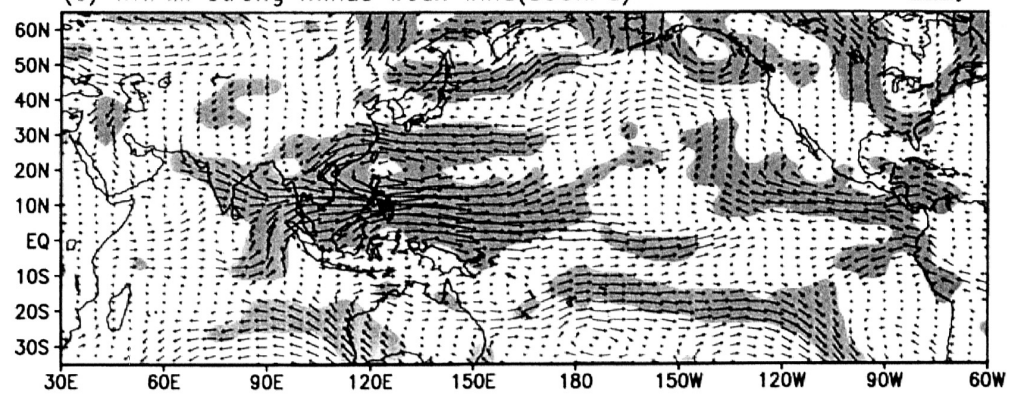

Fig. 11. Composite difference of (a) $200 \mathrm{hPa}$ wind, (b) $500 \mathrm{hPa}$ geopotential height, and (c) 850-hPa wind between strong and weak monsoon years with respect to the WNPMI. The contour interval for the height is $4 \mathrm{~m}$. Shading denotes regions of difference at $95 \%$ confidence level. (from Wang et al. 2001)

A strong Indian monsoon is associated with an enhanced South Pacific subtropical high and an anomalous anticyclone over northeast China (Fig. 12a). An important feature for the WNSP teleconnection is the pattern between the WNPSM and North American summer climate. Suppressed WNPSM rainfall and convective latent heat release are correlated with deficient summer rainfall in the U.S. Great Plains. The wave train is associated with anomalous convection over the WNP and consists of five individual circulation anomaly cells with alternating signs (Fig. 12b). 


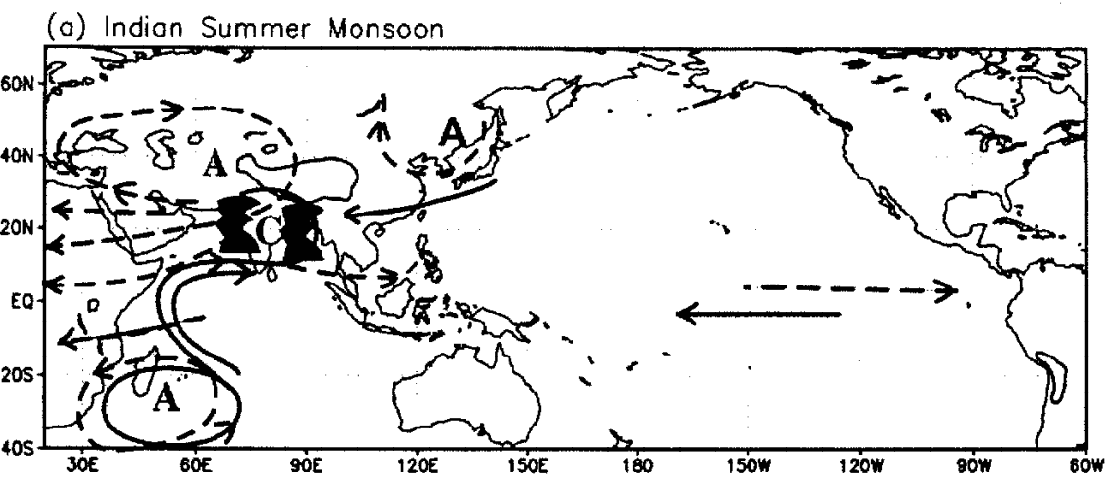

(b) Western North Pocific Summer Monsoon

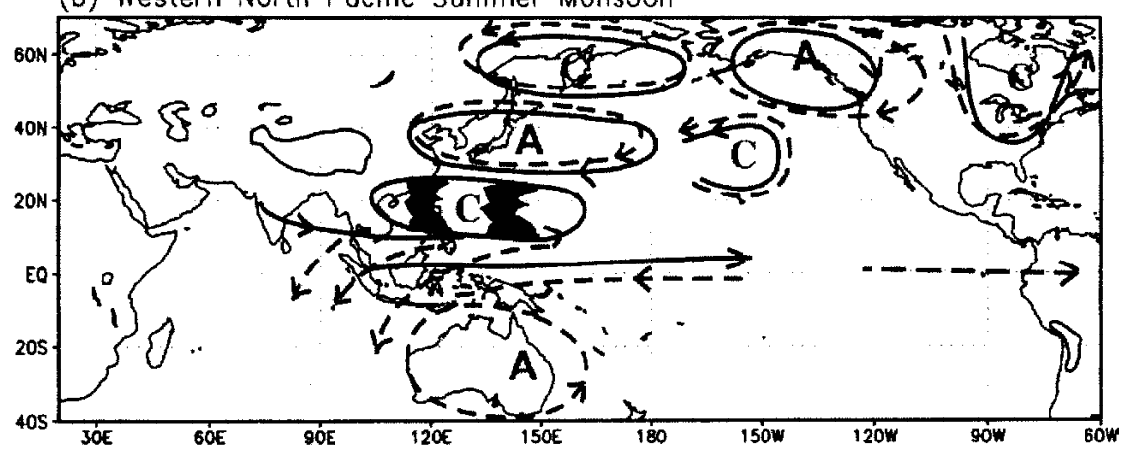

Fig. 12. Schematic diagrams showing the major circulation anomalies associated with a strong IMI (a) and WNPSM (b). The lower-level and upper-level circulation anomalies are denoted by solid and dashed line, respectively. Letter " $A$ " and " $C$ " represent anticyclone and cyclone, respectively. (from Wang et al. 2001)

\section{FINAL REMARKS}

This review summarizes the regional characteristics of the WNP monsoon on various time scales, including its annual cycle, synoptic wave activity, intraseasonal oscillations, and interannual variabilities. For the climatological annual cycle, the WNPSM shows a remarkable step-wise northeastward advance from the SCS to the WNP. Tropical synoptic-scale disturbances often have a wave train structure, propagating northwestward. Tropical intraseasonal oscillations have well-separated two frequency bands in the power spectra of OLR over the WNP. They exhibit large subseasonal variabilities. The ENSO has been identified as a major factor that influences the interannual variability of the WNP monsoon.

While many studies have revealed the observed structure and evolution characters of the WNPSM on various time scales, fundamental physical mechanisms that give rise to such char- 
acters are not fully understood. For example, regarding to the WNPSM annual cycle, it is not clear what causes the step-wise progression and sudden jumps from one stage to others. It is also unclear why the WNP monsoon convection and circulation move eastward in contrast to northward migration in India and East Asia sectors. The EASM experiences a similar stepwise progression and sudden jump of the convection zone. Are their seasonal progressions related? The CISO may play an important role in determining multi onset stages of the WNPSM. On the other hand, the CISO explains less than $20 \%$ of total ISO variances, and it is prominent only in certain regions.

Regarding the ISO, it is still an open question as to why does nature prefers the two significant spectrum peaks. It is unclear why the bi-weekly and lower-frequency ISO modes both move northwestward in the WNP but in opposite directions in the northern Indian Ocean. The origin of the ISO in the WNP is unclear. Wang and Xie (1997) proposed, based on their intermediate model experiment, that it be originated from the equatorial eastward propagating MJO. After the eastward propagating MJO arrives in the central equatorial Pacific, due to the reduced SST and specific humidity, as well as the disappearance of the mean easterly vertical shear, the Rossby-Kelvin wave packet of the MJO tends to be decoupled. As a result, Rossby waves emanate northwestward to the WNP. Another possible scenario is that the ISO may arise from local air-sea interactions (Wang and Xie 1998).

Regarding the interannual variability of the WNPSM, a remarkable feature is its biennial tendency in association with the El Niño turnabout, this is, the WNPSM tends to strengthen in the El Niño developing phase but weaken in the El Niño decaying phase. However, it is not clear what physical processes are responsible for this biennial variability. Are there other factors that determine the interannual variability of the WNPSM in addition to the remote ENSO forcing? It is our hope that with further understanding of these important scientific questions, we will be able to predict complex weather and climate variabilities over the WNP.

Acknowledgements The authors would like to thank Dr. Xianan Jiang, Dr. Yongsheng Zhang, Dr. Randy Wu, Dr. R. H. Zhang, and Ms. Chunhua Zhou for preparing figures and for valuable discussions. TL acknowledges support from NSF Grant ATM01-19490 and ONR Grants N000140310739/N000140210532. International Pacific Research Center is partially sponsored by the Japan Agency for Marine-Earth Science and Technology (JAMSTEC).

This is SOEST contribution number 6584 and IPRC contribution number 330.

\section{REFERENCES}

Aiyyer, A. R., and J. Molinari, 2003: Evolution of mixed Rossby-gravity waves in idealized MJO environments. J. Atmos. Sci., 60, 2837-2855.

Barnett, T. P., 1991: The interaction of multiple time scales in the tropical climate system.J. Climate, 4, 269-285.

Briegel, L. M., and W. M. Frank, 1997: Large-scale influences on tropical cyclogenesis in the western North Pacific. Mon. Wea.Rev., 125, 1397-1413. 
Chang, C. P., J. M. Chen, P. A. Harr, and L. E. Carr, 1996: Northwestward-propagating wave patterns over the tropical western north Pacific during summer.Mon. Wea.Rev., , 22452266.

Chang, C. P., P. Harr, and J. Ju, 2001: Possible Roles of Atlantic Circulations on the Weakening Indian Monsoon Rainfall-ENSO Relationship. J. Climate, 14, 2376-2380.

Chang, C. P., Y. Zhang, and T. Li, 2000a: Interannual and interdecadal variations of the East Asian summer monsoon and tropical Pacific SSTs. Part I: Roles of the subtropical ridge.J. Climate, 13, 4310-4325.

Chang, C. P., Y. Zhang, and T. Li, 2000b: Interannual and interdecadal variations of the East Asian summer monsoon and tropical Pacific SSTs. Part II: Meridional structure of the monsoon. J. Climate, 13, 4326-4340.

Chang, H. R., and P. J. Webster, 1990: Energy accumulation and emanation at low latitudes. Part II: nonlinear response to strong episodic equatorial forcing. J. Atmos. Sci., 47, 26242644.

Chen, T. C., and J. M. Chen, 1993: The 10 - 20 day mode of the 1979 Indian monsoon: Its relation with time variation of the monsoon rainfall. Mon. Wea. Rev., 121, 2465-2482.

Chen, T. C., and M. Murakami, 1988: The 30 - 50 day variation of convective activity over the western Pacific ocean with emphasis on the northwestern region. Mon. Wea. Rev., 116, 892-906.

Chen, T. C., R. Y. Tzeng, and M. C. Yen, 1988: Development and life cycle of the Indian monsoon: Effect of the 30-50 day oscillation. Mon. Wea. Rev., 116, 2183-2199.

Chen, T. C., S. P. Weng, N. Yamazaki, and S. Kiehne, 1998: Interannual variation in the tropical cyclone formation over the western North Pacific. Mon. Wea. Rev., 126, 1080-1090.

Chen, T. C., and M. C. Yen, 1986: The 40 - 50 day oscillation of the low-level monsoon circulation over the Indian Ocean. Mon. Wea. Rev., 114, 2550-2570.

Chen, T. C., M. C. Yen, and S. P. Weng, 2000: Interactions between the summer monsoon in East Asia and South China Sea: Intraseasonal monsoon modes. J. Atmos. Sci., 57, 13731392.

Chou, C., J. Tu, and J. Yu, 2003: Interannual Variability of the Western North Pacific Summer Monsoon: Differences between ENSO and Non-ENSO Years.J. Climate, 16, 2275-2287.

Clarke, A. J., X. Liu, and S. V. Gorder, 1998: Dynamics of the biennial oscillation in the equatorial Indian and far western Pacific oceans. J. Climate, 11, 987-1001.

Compo, G. P., G. N. Kiladis, and P. J. Webster, 1999: The horizontal and vertical structures of East Asian winter monsoon pressure surge. Quart. J. Roy. Met. Soc., 125, $29-54$.

Dickinson, M. J., and J. Molinari, 2002: Mixed Rossby-gravity waves and western Pacific tropical cyclogenesis. Part I: Synoptic evolution. J. Atmos. Sci., 59, 2183-2196.

Ding, Y. H., 1992: Summer monsoon rainfalls in China.J. Meteo. Soc. Japan, 70, 373-396.

Frank, W. M., 1982: Large-scale characteristics of tropical cyclones. Mon. Wea. Rev., 110, 572-586.

Fu, B., 2003: An observational study of tropical cyclone formation in the western North Pacific. Master thesis, Univ. of Hawaii, 225pp. 
Fukutomi, Y., and T. Yasunari, 1999: 10 - 25-day intraseasonal variations of convection and circulation over East Asia and western North Pacific during early summer.J. Meteor. Soc. Japan, 77, 753-769.

Fukutomi, Y., and T. Yasunari, 2002: Tropical-extratropical interaction associated with the 10 - 25-day oscillation over the Western Pacific during the northern summer.J. Meteor. Soc. Japan, 80, 311-331.

Holland, G. J., 1995: Scale interaction in the western Pacific monsoon. Meteor. Atmos. Phys., 56, 57-79.

Hsu, H. H., and C. H. Weng, 2001: Northwestward propagation of the intraseasonal oscillation in the western North Pacific during the boreal summer: structure and mechanism.J. Climate, 14, 3834-3850.

Huang, R., and F. Sun, 1992: Impacts of the tropical western Pacific on the East Asian summer monsoon. J. Meteor. Soc. Japan, 70, 243-256.

Huang, R., and Y. Wu, 1989: The influence of ENSO on the summer climate change in China and its mechanisms. Adv. Atmos. Sci., 6, 21-32.

Jiang, X. T. Li, and B. Wang, 2004: Structures and mechanisms of the northward propagating boreal summer intraseasonal oscillation. J. Climate, 17, 1022-1039.

Ju, J., and J. M. Slingo, 1995: The Asian summer monsoon and ENSO. Quart. J. Roy. Meteor. Soc., 121, 1133-1168.

Kang, I. S., C. H. Ho, and Y. K. Lim, 1999: Principal modes of climatological seasonal and intraseasonal variations of the Asian summer monsoon. Mon. Wea. Rev., 127, 322-340.

Kawamura, R., 1998: Baiu near Japan and its relation to summer monsoons over southeast Asia and the western North Pacific. J. Meteor. Soc. Japan, 76, 619-639.

Kawamura, R., T. Murakami, and B. Wang, 1996: Tropical and midlatitude 45-day perturbations over the western Pacific during the northern summer.J. Meteor. Soc. Japan, 74, 867890.

Kemball-Cook, S., and B. Wang, 2001: Equatorial waves and air-sea interaction in the boreal summer intraseasonal oscillation. J. Climate, 14, 2923-2942.

Krishnamurti, T. N., and D. Subrahmanyam, 1982: The 30 - 50-day mode at $850 \mathrm{mb}$ during MONEX. J. Atmos. Sci., 39, 2088-2095.

Krishnamurti, T. N., and P. Ardanuy, 1980: The 10- to 20-day westward propagating mode and "breaks in the monsoons." Tellus, 32, 15-26.

Krishnamurti, T. N., and H. N. Bhalme, 1976: Oscillations of a monsoon system. Part I: Observation aspects. J. Atmos. Sci., 33, 1937-1954.

Krishnamurti, T. N., and D. Subrahmanyam, 1982: The 3 - 50 day mode ay $850 \mathrm{mb}$ during MONEX. J. Atmos. Sci., 39, 2088-2095.

Kumar, K. K., B. Rajagopalan, and M. A. Cane, 1999: On the weakening relationship between the Indian monsoon and ENSO. Science., 284, 2156-2159.

Kuo, H. C., J. H. Chen, R. T. Williams, and C. P. Chang, 2001: Rossby wave in zonally opposing mean flow: Behavior in northwest Pacific summer monsoon.J. Atmos. Sci., 58, 10351050 . 
Lander, M. A., 1996: Specific tropical cyclone track types and unusual tropical cyclone motions associated with a reverse-oriented monsoon trough in the western north Pacific.Wea. Forecasting, 11, 170-186.

Lau, K. M., and P. H. Chan, 1986: Aspects of the 40 - 50 day oscillation during the northern summer as inferred from outgoing longwave radiation. Mon. Wea. Rev., 114, 1354-1367.

Lau, K. H., and N. C. Lau, 1990: Observed structure and propagation characteristics of tropical summertime synoptic scale disturbances. Mon. Wea. Rev., 118, 1888-1913.

Lau, K. H., and N. C. Lau, 1992: The energetics and propagation dynamics of tropical summertime synoptic-scale disturbances. Mon. Wea. Rev., 120, 2523-2539.

Lau, K. M., J. Y. Lee, K. M. Kim, and I. S. Kang, 2004: The North Pacific as a regulator of summertime climate over Eurasia and north America. J. Climate, 17, 819-833.

Lau, K. M., and H. Weng, 2000: Remote forcing of US summertime droughts and floods by the Asian monsoon? Gewex News, 10, 5-6.

Lau, K. M., and H. Weng, 2002: Recurrent teleconnection patterns linking summertime precipitation variability over East Asia and North America. J. Meteor. Soc. Japan, 80, 11291147.

Lau, K. M., G. Yang, and S. H. Shen, 1988: Seasonal and intraseasonal climatology of summer monsoon rainfall over East Asia. Mon. Wea. Rev., 116, 18-37.

Li, T., 1997: Phase transition of the El Niño-Southern Oscillation: A stationary SST mode. $J$. Atmos. Sci., 54, 2872-2887.

Li, T., 2005: Origin of the summertime synoptic-scale wave train in the western North Pacific. J. Atmos. Sci., submitted.

Li, T., B. Fu, X. Ge, B. Wang, and M. Peng, 2003: Satellite data analysis and numerical simulation of tropical cyclone formation. Geophys. Res. lett., 30, 2122-2125.

Liebmann, B., and H. H. Hendon, 1990: Synoptic scale disturbances near the equator.J. Atmos. Sci., 47, 1463-1479.

Lin, H., and B. Wang, 2002: The time-space structure of the Asian-Pacific summer monsoon: A fast annual cycle view. J. Climate, 15, 2001-2018.

Lu, R., 2001: Interannual variability of the summertime North Pacific subtropical high and its relation to atmospheric convection over the warm Pool. J. Meteor. Soc. Japan., 79, 771783.

Lu, R., and B. Dong, 2001: Westward extension of North Pacific subtropical high in summer. J. Meteor. Soc. Japan., 79, 1129-1241.

Maloney, E. D., and S. K. Esbensen, 2003: The amplification of east Pacific Madden-Julian oscillation convection and wind anomalies during June-November. J. Climate, 16, 34823497.

Maloney, E. D., and D. L. Hartmann, 2001: The Madden-Julian Oscilaltion, barotropic dynamics, and north Pacific tropical cyclone formation. Part I: Observations. J. Atmos. Sci., 58, 25452558.

Meehl, G. A., 1987: The annual cycle and interannual variability in the tropical Pacific and Indian Ocean region. Mon. Wea. Rev., 115, 27-50. 
Murakami, T., 1980: Empirical orthogonal function analysis of satellite-observed, outgoing long-wave radiation during summer. Mon. Wea. Rev., 108, 205-222.

Murakami, T., and J. Matsumoto, 1994: Summer monsoon over the Asian continent and western North Pacific. J. Meteor. Soc. Japan, 72, 719-745.

Nakazawa, T., 1986: Mean features of 30 - 60 day variations as inferred from 8-yr OLR data.J. Meteor. Soc. Japan, 64, 777-786.

Nakazawa, T., 1992: Seasonal phase lock of intraseasonal oscillation during the Asian summer monsoon. J. Meteor. Soc. Japan, 70, 597-611.

Ninomiya, K., and C. Kobayashi, 1998: Precipitation and moisture balance of the Asian summer monsoon in 1991. Part I: Precipitation and major circulation systems. J. Meteor. Soc. Japan, 76, 855-877.

Ninomiya, K., and C. Kobayashi, 1999: Precipitation and moisture balance of the Asian summer monsoon in 1991. Part II: Moisture transport and moisture balance. J. Meteor. Soc. Japan, 77, 77-99.

Nitta, T., 1987: Convective activities in the tropical Western Pacific and their impact on the Northern Hemisphere summer circulation. J. Meteor. Soc. Japan, 65, 373-390.

Rasmusson, E. M., X. L. Wang, and C. F. Ropelewski, 1990: The bieenial component of ENSO variability. J. Mar. Sys., 1, 71-96.

Reed, R. J., and E. E. Recker, 1971: Structure and properties of synoptic-scale wave disturbances in the equatorial western Pacific. J. Atmos. Sci., 28, 1117-1133.

Ritchie, E. A., and G. J. Holland, 1999: Large-scale patterns associated with tropical cyclogenesis in the western Pacific. Mon. Wea. Rev., 127, 2027-2043.

Sikka, D. R., and S. Gadgil, 1980: On the maximum cloud zone and the ITCZ over Indian longitudes during the southwest monsoon. Mon. Wea. Rev., 108, 1840-1853.

Straub, K. H., and G. N. Kiladis, 2003: Interactions between the boreal summer intraseasonal oscillations and high-frequency tropical wave activity. Mon. Wea. Rev., 131, 781-796.

Sui, C. H., and K. M. Lau, 1992: Multi-scale phenomena in the tropical atmosphere over the western Pacific. Mon. Wea. Rev., 120, 407-430.

Takayabu, Y. N., and T. Nitta, 1993: 3-5 day disturbances coupled with convection over the tropical Pacific Ocean. J. Meteor. Soc. Japan, 71, 221-245.

Tanaka, M., 1992: Intraseasonal oscillation and the onset and retreat dates of the summer monsoon over East, Southeast Asia and the western Pacific region using GMS high cloud amount data. J. Meteor. Soc. Japan, 70, 613-629.

Tanaka, M., 1997: Interannual and interdecadal variations of the western North Pacific monsoon and the East Asian Baiu rainfall and their relationship to ENSO cycles.J. Meteor. Soc. Japan, 75, 1109-1123.

Tao, S., and L. Chen, 1987: A review of recent research on the East Asian summer monsoon in China. Monsoon Meteorology. Chang, C. P., and T. N. Krishnamurti, (Eds.), Oxford University Press. 60-92.

Teng, H., and B. Wang, 2003: Interannual Variations of the Boreal Summer Intraseasonal Oscillation in the Asian-Pacific Region. J. Climate, 16, 3572-3584. 
Ueda, H., T. Yasunari, and R. Kawamura, 1995: Abrupt seasonal changes of large-scale convective activity over the Western Pacific in the northern summer.J. Meteor. Soc. Japan, 73, 795-809.

Wallace, J. M., 1971: Spectral studies of tropospheric wave disturbances in the tropical western Pacific in the tropical western Pacific. Rev. Geophys. Space. Phys., 9, 557-612.

Wallace, J. M., and C. P. Chang, 1969: Spectral analysis of large-scale wave disturbances in the lower tropical troposphere. J. Atmos. Sci., 26, 1010-1025.

Wang, B., 1995: Interdecadal changes in El Niño onset in the last four decades. J. Climate, 8 , 267-285.

Wang, B., and J. C. L. Chan, 2002: How strong ENSO events affect tropical storm activity over the Western North Pacific. J. Climate, 15, 1643-1658.

Wang, B., and Z. Fan, 1999: Choice of South Asian Summer Monsoon Indices. Bull. Am. Meteor. Sci., 80, 629-638.

Wang, B., and Lin H., 2002: Rainy seasons of the Asian-Pacific monsoon.J. Climate, 15, 386398.

Wang, B., R. Wu, and X. Fu, 2000: Pacific-East Asia teleconnection: How does ENSO affect East Asian climate? J. Climate, 13, 1517-1536.

Wang, B., R. Wu, and K. M. Lau, 2001: Interannual variability of Asian summer monsoon: Contrast between the Indian and western North Pacific-East Asian monsoons.J. Climate, 14, 4073-4090.

Wang, B,. R. Wu, and T. Li, 2003: Atmosphere-warm ocean interaction and its impact on Asian-Australian monsoon variation. J. Climate, 16, 1195-1211.

Wang, B., R. Wu, and R. Lukas, 1999: Roles of the western North Pacific winds in thermocline adjustment and ENSO phase transition. J. Meteor. Soc. Japan, 77, 1-16.

Wang, B., and X. Xie, 1996: Low-frequency equatorial waves on vertically sheared zonal flow. Part I: Stable waves. J. Atmos. Sci., 53, 449-467.

Wang, B., and X. Xie, 1997: A model for the boreal summer intraseasonal oscillation.J. Atmos. Sci., 54, 72-86.

Wang, B., and X. Xie, 1998: Coupled modes of the warm pool climate system. Part I: The role of air-sea interaction in maintaining Madden-Julian Oscillation.J. Climate, 11, 2116-2135.

Wang, B., and X. Xu, 1997: Northern hemisphere summer monsoon singularities and climatological intraseasonal oscillation. J. Climate, 10, 1071-1085.

Wang, B., and Q. Zhang, 2002: Pacific-East Asian teleconnection, part II: How the Philippine Sea anticyclone established during development of El Niño. J. Climate, 15, 3252-3265.

Webster, P., and S. Yang, 1992: Monsoon and ENSO: Selectively interaction system.Quart. J. Meteor. Soc., 66, 398-412.

Wu, G., et al., 2002: Dynamics of formation and variability of subtropical high. Science Press (in Chinese), 314pp.

Wu, R., 2002: Processes for the northeastward advance of the summer monsoon over the western North Pacific. J. Meteor. Soc. Japan, 80, 67-83. 
Wu, R., and B. Wang, 2000: Interannual variability of summer monsoon onset over the western North Pacific and the underlying processes. J. Climate, 13, 2483-2501.

Wu, R., and B. Wang, 2001: Multi-stage onset of the summer monsoon over the western North Pacific. Climate. Dyn., 17, 277-289.

Yamazaki, N., and M. Murakami, 1989: An intraseasonal amplitude modulation of the shortterm tropical disturbances over the western Pacific. J. Meteor. Soc. Japan, 67, 781-807.

Yasunari, T., 1979: Cloudiness fluctuations associated with the Northern Hemisphere summer monsoon. J. Meteor. Soc. Japan, 57, 227-242.

Yasunari, T., 1980: A quasi-stationary appearance of 30- to 40-day period in the cloudiness fluctuations during the summer monsoon over India. J. Meteor. Soc. Japan, 58, 225-229.

Zhang, Y., and S. Jiang, 2000: Retrieval of the tropical divergent wind from OLR and its application in ENSO diagnosis. Acta Meteor. Sin., 14, 61-81.

Zhang, Y., T. Li, and B. Wang, 2004: Decadal change of snow depth over the Tibetan Plateau in spring: The associated circulation and its relationship to the East Asian summer monsoon rainfall. J. Climate, 17, 2780-2793.

Zhang, R., A. Sumi, and M. kimoto, 1996: Impact of El Niño on the East Asia Monsoon: A diagnostic study of the '86/87 and '91/92 events. J. Meteor. Soc. Japan, 74, 49-62.

Zhang, R., and A. Sumi, 2002: Moisture circulation over East Asia during El Niño episode in northern winter, spring and autumn. J. Meteor. Soc. Japan, 80, 213-227. 